\title{
VERDADE, NOVO CÓDIGO DE PROCESSO CIVIL \\ E A REGRA DA CARGA PROBATÓRIA DINÂMICA
}

Francisco Bertino Bezerra de Carvalho

Professor Adjunto da UFBa de Direito Processual Civil e Prática Jurídica Cível, advogado, Procurador do Município do Salvador, Mestre em Direito Econômico pela UFBa e Doutor em Direito Público pela UFBa.

\section{Resumo}

O trabalho introduz a questão da verdade como humana experimentada na intersubjetividade e a insere nos desafios da comunicação, retornando ao tema à luz da introdução da distribuição dinâmica da carga probatória no projeto do NCPC. Apresenta o direito como fenômeno cultural e sua relação com a verdade em dois planos, o da verificação da ocorrência dos fatos jurídicos e o da incidência das normas nos casos concretos. Inclui o processo como instrumento do direito para construção, no plano real, de seu projeto de regulação da conduta. A partir destas premissas, examinam-se a tangibilidade da verdade, as formas de sua compreensão pelo homem, assim como a atualidade e a importância da questão da verdade nas sociedades, ainda que para a manutençáo do compromisso com a verdade possível. Visita-se a relação da verdade com a linguagem, com o direito e com o processo para se concluir que o processo é a busca da verdade pelo direito para entrega, à sociedade, da verdade do direito e que a produçáo jurisdicional do direito desafia tripla legitimação, pela fundamentação, pelo procedimento e pelo diálogo comunicativo de Habermas, aplicado no âmbito processual. Identificada a recepção pelo NCPC da teoria das cargas probatórias dinâmicas como a modificação com maior pertinência com a questão da busca da verdade fática no processo civil, a analisa pela perspectiva proposta.

\section{Palavras-chave}

Verdade; Novo Código de Processo Civil; Carga probatória dinâmica.

\section{Abstract}

The paper conceives the truth as a human creation, intersubjectively perceived, and places it throughout the challenges of communication, returning to this subject in the way from theory of the dynamic evidenciary burdem. It presents Law as a cultural phenomenon and also its connection with the truth from two perspectives: the first of verifying 
the occurrence of legal facts and the other the incidence of legal rules in concrete cases. It also contemplates legal procedure as an instrument to construct, amidst reality, its purpose of regulating conduct. From these premises, the paper examines the tangibility of truth, the forms of its comprehension by men, as well as the contemporariness and importance of the truth within societies, even for the maintenance of the commitment to the possible truth. The paper visits the connection of the truth with Linguistics, Law and legal procedure, concluding at last that the latter is the search of truth, in a procedural system, to surrender to the society the truth of law and that the jurisprudence faces a triple legitimation, through the motivation, the procedure and the Habermas' communicative dialogue, applied over a procedural spectrum. Identified the receipt by the New Code of Civil Procedure the theory of dynamic evidentiary burdens as modification with greater relevance to the issue of search factual truth in civil proceedings, analyzes it from the perspective proposal.

\section{Key words}

Truth; New Code of Civil Procedure; Dynamic evidentiary burdens.

\section{Introdução: A Verdade, o Homem, o Direito e o Processo}

A verdade é uma preocupação humana universal, presente em todas as culturas e sociedades, ainda que em cada época e lugar o problema - e sua solução - tenha se revestido de peculiaridades, cuja extensão, porém, não é capaz de extrair a identidade. Uma das mais importantes ou "a" questão da filosofia perpassa por todo o conhecimento e toda a existência humana, desafio permanente para qualquer área de ação ou ramo de reflexão de homens e mulheres, a verdade reveste-se de especiais circunstâncias quando se vincula à aplicação do direito por meio do processo judicial. Por outro lado, é tempo de reconhecer a importância do estudo filosófico do direito processual como adverte Henrique Garbellini Carnio (2014, 368).

Todo aglomerado humano capaz de se comunicar enfrenta a o desafio da confirmação, ou infirmação, das informações transmitidas e/ou trocadas, seja para questóes de menor relevância, seja para aquelas necessárias à sobrevivência do indivíduo e/ou da comunidade. A verdade que pode ser objeto de apreensão na perspectiva que se pretende é a coletiva, no sentido de compartilhável e compartilhada, ou seja, originada da vida em sociedades humanas. $\mathrm{O}$ mundo de pensamentos, percepçóes e crenças náo exteriorizadas que povoam apenas o subjetivismo particular de cada um, não obstante real e "verdadeiro" para o sujeito experimentador é estranho ao conceito de verdade que se objetiva aqui abordar, vinculado e restrito à intersubjetividade, à pluralidade de sujeitos. 
A questão em derredor da verdade, todavia, não se restringe apenas ao âmbito acadêmico de complexas discussóes, como acredita parte da população desavisada da mundanidade e atualidade de todos os dilemas de ordem filosófica, ao revés. Assim, a abordagem pretendida busca, de um lado, a partir de uma reflexão sobre a verdade e sua relaçáo com o homem, entender como o direito e o processo tentam (e em que medida conseguem) estabelecer uma relação com a verdade, e, de outro lado, analisar em que medida a introdução no ordenamento processual brasileiro da teoria das cargas probatórias dinâmicas contribui ou atrapalha a esta relação.

O direito - fenômeno cultural que é - está sujeito aos influxos da condição humana ${ }^{i}$ e não poderia ser indiferente à questão da verdade. Seja como instrumento de dominação, controle, regulaçáo ou fomentador da cooperaçáo entre os homens, o direito precisa valer para cumprir seu papel social, no que se depara com a verdade em duas vertentes: 1) na ocorrência do fato (o fato é a matéria prima do direito), pois na apreciação da veracidade da ocorrência no mundo real do fato previsto hipoteticamente no ordenamento opera-se a primeira verificação de verdade necessária à aplicação concreta do direito - uma verdade fenomenológica, e; 2) na relação de incidência (o direito é um projeto de conduta conforme ou de reaçáo institucionalizável à sua inobservância), ou seja, esta segunda verificaçáo de verdade opera no plano da eficácia da norma jurídica, ou seja, se, no caso concreto, o direito efetivamente se fez aplicar - uma verdade social ou cultural.

O processo - instrumento do direito - é uma prática (técnica) destinada (sem sempre capaz) a construir normas individuais concretizadoras no plano real do direito em situaçóes específicas - na existência de conflitos ou nas circunstâncias previstas no ordenamento em que o resultado jurídico pretendido dependa de pronunciamento jurisdicional ${ }^{1}$ - se depara com a verdade em dois prismas reflexos daqueles enfrentados pelo direito, na verificaçáo do fato (almejando encontrar os mecanismos de desvendar a verdadeira ocorrência sobre a qual deveria debruçar-se o órgão julgador) e na aplicação do direito (buscando fórmulas confiáveis e estáveis de construir a solução jurídica do caso concreto) de forma que o fenômeno social e cultural do direito receba a adjetivação de verdadeiro. A ciência do direito faz tempo lida com os efeitos sobre seu objeto de estudo do atrito entre concepçóes com a do racionalismo dogmático de Reneé Descartes, Godofredo Guilherme Leibniz e Baruch Espinoza e o empirismo cético de Francis Bacon, David Hume e John Locke. Mesmo de Immanuel Kant a Edmund Husserl continua-se em uma variação sobre o mesmo tema.

Assim, para poder atribuir-se socialmente o adjetivo verdadeiro ao direito no plano concreto, é preciso conjugar aditivamente uma verdade fática com uma verdade jurídica, aplicando-se o direito verdadeiro sobre um fato igualmente verdadeiro. Em sentido

1 Como na jurisdição constitucional abstrata, na execução forçada de cláusula compromissória ou no inventário envolvendo menores. 
oposto, tanto se o fato considerado para feito de incidência não tiver correspondência com a realidade, quanto se a aplicação não for verdadeira (correta), a hipótese é de um não direito, ou de um falso direito. Em termos de uma abordagem puramente lógica, se fosse cabível, o direito encontraria seu patamar de validade quando reunisse por conectivo lógico da conjunção duas afirmativas validades, a do plano fenomenológico e a do próprio plano de sua aplicação, lembrando que a proposição resultante da conjunção só será verdadeira quando as proposiçóes simples individuais forem verdadeiras.

Náo se pretende incluir o direito na lógica formal do ser, mas realçar que a função de acomodar expectativas requer o reconhecimento de que a segurança jurídica pressupóe resultados esperados, ainda que não únicos, mas se não totalmente previsíveis, não estranhos ou antagônicos ao sistema. Em outras palavras, um direito do qual se possa esperar tudo, ou nada, simplesmente não serve. A questão da verdade se insere neste ponto.

Não é recente a relação intrincada do ser humano com a verdade, novidade "súbita, perigosa e inusitada" (FERNANDEZ-ARMESTO, 2000, p.10) é a aparente irrelevância que a questấo tem assumido ultimamente nas sociedades ocidentais pós-modernas como denuncia, curioso para saber "como chegamos ao ponto em que estamos na história da verdade: como nossa sociedade chegou a perder a fé em sua realidade e a perder o interesse em procurá-la" (2000, p. 16), situaçáo cujos reflexos no direito e no processo, como obras culturais e humanas já se faz sentir.

A complexa questão que se intenciona propor a investigação, se desdobra em duas perguntas: a) partindo da imprescindibilidade e atualidade da questão da busca da verdade, como, em uma época de descrença na verdade em si e na importância de sua procura, manter o comprometimento com a tentativa de realização pelo direito e pelo processo, ao menos, da verdade possível e, ainda, contribuir para que o direito e o processo possam tornar-se cada vez mais instrumento desta procura? b) em que medida a adoção da teoria das cargas probatórias dinâmicas pode contribuir para aproximar ou afastar o direito da verdade?

\section{A Tangibilidade da Verdade}

A abordagem da verdade tem normalmente duas vertentes: a que objetiva a verdade em si, seu conhecimento ou desvelamento, e; a que aborda as possibilidades de relaçáo entre o homem e a verdade. A importância de se descobrir se há verdade e onde se pode encontrá-la é a mesma de se estabelecer a condição humana de, deparando-se com ela, a reconhecer.

Na alegoria da caverna Platão, estruturante de todo o pensamento ocidental, semeou para sempre a dúvida na correlação entre a verdade (realidade) e o passível de percepção, distância que o passar dos anos e o desenvolvimento da ciência somente fez crescer. A 
dificuldade, quiçá impossibilidade de captar o real, não elimina, como pode parecer à uma análise apressada, a questão da verdade, apenas a coloca em outros planos. Tanto é cientificamente possível sustentar a busca da verdade por outros meios capazes de superar as limitações dos sentidos humanos, quanto é moralmente aceitável exigir que o homem permaneça comprometido com toda a verdade que tiver capacidade de conhecer ou ter acesso.

Recomeçando pelo prisma do cogito ergo sum² da filosofia moderna, semeado desde que Parmênides propôs o "não há nada que não exista", ou nega-se a existência de tudo, inclusive do emissário da idéia, ou se tem que admitir a existência de algo. A primeira hipótese elimina todas as questóes. A segunda implica em retomar o problema da verdade enquanto manifestação da coexistência humana, e, por conseqüência, o de como chegar à ela.

Assim, aceita a premissa de que a existência é real, a verdade assume seu lugar de destaque na estruturação das relaçôes sociais. Quem se dedicou a estudar a história da verdade, ou melhor, a verdade pelo prisma e como objeto de um estudo pela história, como Felipe Fernández-Armesto (2000), registra a existência de quatro formas de compreensão da verdade pelos povos que se alternam historicamente na experiência das sociedades: a) a verdade conhecida pela emoção, por percepção não racional e não sensorial; b) a verdade que é dita(da) pelos tradutores autorizados aos demais que não teriam acesso ao "mundo da verdade"; c) a verdade da razão, apreendida por métodos racionais de lógica e de argumentação, e; d) a verdade perceptível e compreensível por meio dos sentidos.

O direito, como não poderia deixar de ser, se ocupou da busca da verdade, em especial no âmbito processual, no qual a presença constante do litígio impunha quase sempre uma escolha entre duas ou mais "verdades", fossem fáticas, fossem jurídicas.

Se o direito medieval conviveu com meios de prova influenciados pela fé religiosa (LIMA, 2013, P. 606) como as ordálias, desde a revolução científica recusa-se no mundo jurídico uma a verdade conhecida pela emoção, por percepção não racional e não sensorial. Dos outros três modelos, todavia, o direito se utiliza - simultaneamente inclusive. A verdade perceptível comumente serve aos meios de prova - testemunho, inspeção, perícia, etc. - e a verdade da razão no debate jurídico sobre a subsunção - partes, juízo e todos aqueles que atuam no processo dela se valem. A verdade oriunda dos tradutores autorizadas, mais associada à religião, tem uma conotação especial no mundo jurídico, pois ele também se vale de tradutores autorizados para dizer aos demais a verdade do direito, não sendo outro o sentido de jurisdição. Estas, porém, são sempre facetas da verdade, etapas para atingir o consenso. Assim, no plano da controvérsia fática, prevalece a busca da verdade perceptível. No plano da controvérsia jurídica, o embate próprio da verdade racionalizável, em especial na construção e consolidação de significados, como nos lembra Luis

2 Ou sua variante, no pensamento oriental, da escola Nyaya de comentaristas dos vedas: lembro, logo existo. 
Assier-Andrieu: "O direito existe a princípio nomeando e qualificando, é arte de linguagem, é acima de tudo palavra." (2000, p. 314). Ambas, porém, acontecem atreladas à construção da verdade jurídica pelos tradutores autorizados: todos os cidadãos, em nível primário e precário, os magistrados em nível final e definitivo. A competência dada aos magistrados de dizer o direito de forma definitiva, amplia a importância no direito processual civil da discussão sobre a verdade. Todas, ao final, constroem a verdade coletiva.

A verdade prossegue sendo matéria prima e produto final do direito, ainda que se possa considerar tal produto final como uma verdade convencional, inserida social, política e culturalmente em um horizonte específico, pois isto não corrompe sua essência nem reduz sua importância. Ao contrário da impressão que se possa ter, a verdade continua uma questão central do direito, especialmente do processo.

A obra de Felipe Fernández-Armesto (2000) relata a desilusão experimentada pelas sociedades pós-modernas com a verdade e com a relevância de sua busca, assim como as nefastas consequências desta nova postura tão evidente, quanto pouco analisada e a necessidade de resgatar a verdade:

Anteriormente, esses esforços foram dirigidos para salvar a verdade. Agora, é muito tarde para isso; é preciso recuperá-la de dentro da goela do ceticismo e ressuscitá-la. Trata-se de uma tarefa urgente: uma vez que a verdade foi devorada, as pessoas engolem falsidades por inteiro. Sem confiança no conceito de verdade, os ouvintes não dispõem de armas contra mentiras. (FERNÁNDEZ-ARMESTO, 2000, 193)

Precisamos, talvez mais do que nunca, da verdade, talvez não aquela que conforte e tranquilize a sociedade, mas com certeza aquela que for capaz de produzir.

O erro original, no caso, é tentar conceber e tratar os fenômenos culturais a imagem e semelhança dos naturais. É preciso descontaminar as manifestaçóes culturais - como a arte e o direito - do paradigma da comprovação científica nos moldes aplicáveis às ciências exatas, buscando encontrar e ressaltar em sua própria natureza sua importância, validade e verdade. O cultural é - e sempre será - a verdade coletivamente construída (a única objetivável), impregnada por sua humanidade, com toda sua grandeza e limitação e, por isso mesmo, de importância central na existência e coexistência.

As certezas, nesta época de incertezas, na qual, como diz Felipe Fernández-Armesto, "A dúvida é a verdade de nossos tempos" (2000, p. 238) podem ser buscadas na própria humanidade e na sua história. O tempo, mais esta ilusão útil dos sentidos humanos, pode ser utilizado pelos homens mais do que para registrar o direito na história, uma vez que a compreensão da relevância da inserção histórica e existencial do intérprete na sua atividade não diminuiu a importância de sua tarefa, apenas a aumentou.

É preciso, portanto, combater o desapego à verdade e o desinteresse pela luta por ela. Para isso, é preciso conhecer as origens do processo. Dentre as raízes desta erva daninha 
destaca-se o individualismo, como assevera Felipe Fernández-Armesto, para quem "Em qualquer sistema que se inicie com a consciência individual, existe o perigo de se valorizar igualmente todas as opinióes" (2000, p. 194) em companhia do voluntarismo, do subjetivismo, do existencialismo e do pragmatismo, estes dois últimos, mais determinantes no naufrágio da verdade que soçobrou na era das incertezas que se desenvolveu conjuntamente a repercussão das teorias da relatividade, do caos e desconstrução da matemática por Kurt Gödel. Em outras palavras: se o tempo e o espaço são relativos, o movimento das asas de uma borboleta em um hemisfério causava ciclones no outro e nem matemática nem lógica são suficientes para comprovar a si mesmas, que verdade seria alcançável? E para quê?

Por outro lado, o relativismo que tomou conta do mundo também seduz por adequar-se à uma ideologia dominante, qual seja a da globalização, pois em um mundo cosmopolita, multicultural, nada aparentemente mais conveniente para pacificar a convivência de pessoas e culturas diferentes do que o ilusório conforto de acreditar que todos podem ter razáo simultaneamente. A verdade, ou a busca dela, poderia, nesta concepção, semear a discórdia e a até mesmo a guerra.

Esta aposta na incerteza como fator de cooperação, ou, ao menos aglutinação, porém, revela-se equivocada porque trabalha com uma premissa errada: a de que a irrelevância da correção das verdades de cada um torna todos mais tolerantes com as verdades alheias. O relativismo, ao revés gera, no plano pessoal, a sensação de insegurança (e a inquietude que lhe é peculiar) e, no plano social, fomenta a mais danosa atitude em face da comunidade, a conveniência.

A conjugaçáo destes fatores desagrega em um nível o tecido social que sua ruptura torna-se inevitável. A quase ausência de solidariedade nas comunidades pós-modernas e a própria dificuldade de legitimação das instituiçôes comunitárias, têm correlação com esta perspectiva individualista de encarar a vida e o mundo especialmente com relação ao Estado:

No sería una definición impropria de la política de estos tiempos decir que
ella busca la unidad social. Cualquier problema político des esta cuestión
fundamental está relacionado con los tiempos pasados. ¿Hasta qué punto
y de qué manera es una unidad la sociedad contemporánea? ¿¿Hasta qué
punto hay un interés del conjunto, un interés monista, que trasciende al
interés de las partes que contituyen el todo? (LASKI, [s.d.], p.12).

Não que a verdade esteja no Estado ou se aglutine em torno dele, mas que a dificuldade de encontrar consenso coletivo afeta tanto a existência dele quanto a construçáo de verdades sociais, desaguando a sociedade no relativismo conveniente. A esperada (e cada dia mais visível) reação ao relativismo é o crescimento do fundamentalismo com sua proposta de fornecer o conforto das certezas absolutas para aplacar a insegurança dos mais incomodados. Um dos problemas de toda postura fundamentalista (e de seus 
movimentos) é que o aparente "bem" que faz aos seus seguidores em pacificação traduz-se em um efetivo mal para todos os outros estranhos às crenças que compartilham. Os fundamentalistas radicais não se contentam em abraçar suas verdades absolutas, pretendem impô-las ao resto do mundo, ou, de outra forma, eliminar todos aqueles que as refutem. O fundamentalismo (religioso, estatal, desportivo, de gênero, classe, raça, etc.) constitui ameaça para qualquer pensamento coletivo sobre verdade, política, coexistência, ou qualquer valores morais ou sociais que demandem construção pelo consenso, pelo diálogo ou, ao menos, pelo respeito à diferença.

Desta forma, é uma ilusão crer que o relativismo imperante, que solapa a idéia de valor da verdade e da importância de sua busca, seja benéfico ao projeto de globalização, assim como é insustentável defender a possibilidade de vida harmônica no planeta fundada em perspectivas individualistas da existência e da convivência. Indo mais fundo, concordando-se com a posição de cientistas e ecologistas, que nem mesmo a própria condição da vida (humana) se sustenta diante da globalização (generalização) de padróes de comportamento (especialmente de consumo) individualistas, egocêntricos ou etnocêntricos.

Neste ponto é interessante retomar a correlação da verdade com a intersubjetividade, pois não é mero acaso a relação inversamente proporcional estabelecida entre o avanço do individualismo e o retrocesso da verdade. De fato, quando a verdade torna-se algo individualmente conveniente ${ }^{3}$, perde-se qualquer sentido em sua busca, pois ela somente interessa socialmente quando pode ser compartilhada.

Neste contexto, o processo como instrumento do direito sofre reflexamente os efeitos da incredulidade e do ceticismo com os quais a sociedade passa a enxergar o mundo jurídico. As complexas sociedades pós-modernas, nas quais o direito vem substituindo - mais por necessidade do que por vocação - o papel da solidariedade na conformaçáo das relaçóes sociais, requerem com urgência o resgate da validade do discurso jurídico ${ }^{4}$ e, acima de tudo, da verdade como elemento necessário à comunicação humana, inclusive pelo direito. O processo é parte desta solução e uma nova codificação sempre uma semente de esperança.

A verdade humana se apresenta como um segmento de reta tangente do círculo da realidade da vida, que dele se aproxima para, após tocá-lo por um átimo, dele se afastar. A frugalidade deste momento não reduz sua intensidade ou importância. Se reter a verdade não pertence ao homem, busca-la é sua natureza essencial.

3 Como em Soren Kierkegaard: "Somente a verdade que edifica é verdade para ti" para quem verdade seria qualquer coisa que fizesse o indivíduo viver melhor ou em William James quando sustentava que a verdade não era uma questấo da realidade do que é afirmado, nas de sua possibilidade de corresponder a um propósito particular.

4 Não se trata aqui do conteúdo do discurso e da necessidade de sua alteração inclusive para efeito de legitimação, que é um outro problema. 


\section{A Importância da Verdade Possível}

Se devemos buscar este instante de revelação, é preciso indagar o que é a verdade? É algo que sentimos e experimenta-se pessoalmente com a afetividade individual? É a algo que é desvelado aos demais por aqueles capazes de, individual ou coletivamente, racional ou emocionalmente a apreender? É algo compreensível racional e/ou logicamente? $\mathrm{Ou}$ algo que somente poderia ser compreendida por meio dos nossos sentidos? Algumas destas opçôes apresentadas pela abordagem histórica de Felipe Fernández-Armesto atende?

Os falíveis sentidos humanos e seus sentimentos pessoais fornecerão impressóes particulares, não compartilháveis. A verdade de alguns poucos sempre serviu à dominação de muitos. Resta a opção mais desafiadora: a verdade compreensível racional ou logicamente, aquela que desafia a comunicação e o entendimento, a construída pelo diálogo, limitada pelas condiçóes humanas, especialmente de comunicação. A impossibilidade do homem se apoderar da verdade absoluta, porém não elimina o problema da verdade. Ainda se pode querer a verdade absoluta além da percepção do homem, mantendo acesa a busca por esta verdade, ou exigir do homem, ao menos, toda a verdade que puder entregar a cada momento.

A dificuldade de se atingir a verdade não deve ser obstáculo a valorização da mesma, pois tal valor vem da comparação com seu oposto: a não verdade. A mentira, a dissimulação, frise-se, não é admitida por nenhuma sociedade como intrinsecamente negativa, ruim ou malévola. A rigor, o que importa é a circunstância na qual a não correspondência é utilizada conscientemente, excluindo-se da observação também a mentira inconsciente, aquela dita quando o orador crê estar dizendo a verdade, a qual, mesmo objetivamente indesejada, não enseja repúdio moral inclusive por não poder ser evitada pelo sujeito.

De fato, há várias situaçóes aceitas socialmente nas quais a verdade é propositalmente abandonada, mas que recebem a aprovação popular, não apenas na chamada "mentira inocente", para proteger um ente fragilizado de uma notícia ruim, mas como ocorre na narrativa das fábulas ${ }^{5}$, contos e crenças ${ }^{6}$, nos jogos ${ }^{7}$ e disputas $^{8}$, amadores ou profissionais,

5 O uso do fantástico é mais do que um recurso do discurso, é um apelo à imaginaçáo e, por conseqüência, um acesso ao subjetivo do ouvinte utilizado para obter um resultado específico pretendido de vincular emocionalmente o receptor com a mensagem e, via de regra, com a lição implícita, normalmente moral. A importância social da própria verdade, por exemplo, é passada subliminarmente na fábula de Pedro e o Lobo.

6 Não é por acaso que a obra de Felipe Fernández-Armesto sobre a verdade se inicia com longa digressão acerca dos conflitos originados nos adultos na abordagem da verdade sobre a não existência de Papai Noel.

7 O drible, o blefe.

8 Os golpes nas lutas, dentre as quais a capoeira, por sua origem, destaca-se na arte da dissimulação. 
em estratégias de sobrevivência individual ${ }^{9}$ ou coletiva ${ }^{10}$, como é muito comum nas guer$\operatorname{ras}^{11}$. A mentira torna-se indesejada apenas quando contamina o discurso comunicativo, quando aparece no lugar onde a expectativa era de se encontrar a verdade.

Assim, é preciso deixar claro quando a verdade é valorada: na comunicação que pretende (ou deve) ser exata e precisa. Independentemente da questão da verdade ser plenamente atingível pelo homem ou constituir, em si, um valor absoluto, a idéia proposta é a da importância de se manter socialmente relevante o compromisso com a verdade possível, ou seja, não é porque o homem desconhece toda a verdade absoluta que deverá deixar de transmitir a totalidade da verdade que conhece quando instado a revelá-la.

A verdade já foi, e deve voltar a ser, o ouro, não apenas na analogia primeva que associava a virtude da verdade na comparação do ouro verdadeiro com o falso, mas acima de tudo na simbologia da riqueza, do valorizado, do procurado, do aspirado por uma sociedade.

A consciência da existência, acima de qualquer outra coisa, incertezas. A busca da verdade sempre significou a procura do em "que acreditar além da própria morte" (que seria a única inexorável certeza trazida pela consciência de si mesmo). Desvendar os mistérios da existência parece traduzir e representar a luta contra a morte. Por isto é táo visceral crer em algo - e tem se revelado tão incômodo viver nesta época de incertezas e relativismos.

Como adverte Felipe Fernández-Armesto, o contrário de acreditar profundamente em alguma coisa não tem sido acreditar em nada, mas acreditar em qualquer coisa (2000, p. 17), fenômeno palpável nas sociedades pós-modernas, nas quais todas as convicçóes parecem etéreas. A indefinição dos valores somente semeia mais confusão nas escolhas

9 É solitária, episódica e, acima de tudo, impopular (no sentido de recusada pelo senso comum, este de enorme relevância para a construçấo social da verdade possível), a concepçáo de Kant acerca do dever de dizer a verdade para um assassino, quando sua ocultaçáo salvaria a vida de um amigo ou ente próximo.

$10 \mathrm{O}$ passado político do país deu publicidade e repercussão positiva à declaração da entấo Ministra de Estado (e atual Presidente Dilma Rousseff) que, em depoimento no Poder Legislativo retrucou a acusação adversário (Agripino Maia) de poder ser insincera naquela oportunidade porque já admitira ter mentido em depoimentos prestados sob tortura durante o regime de exceção, argumentando, em suas palavras, que a verdade era própria do regime democrático, do embate franco entre iguais, mas que entre torturador e torturado, a mentira não apenas dignificava o último, como ainda preservava vida de terceiros. É um exemplo de como a circunstância influencia a valoraçấo da verdade (e da mentira). No episódio, a popularidade positiva alcançada pela então Ministra projetou seu nome no Executivo e, de certa forma, colaborou no processo político de escolha pelo Presidente Lula da atual Presidente Dilma Rousseff com sua sucessora.

11 Não apenas a conduta de mentir ao inimigo é esperada de cada combatente, como muitas táticas de combate se estruturam na dissimulação, no engodo do adversário, em diversas formas de fazê-lo crer no que não existe ou desconhecer o que existe. $\mathrm{O}$ combatente que, mesmo torturado pelo inimigo, consegue não dizer a verdade para não prejudicar o esforço de guerra de seu exército, ou, mais especificamente, preservar a vida de seus companheiros, é reconhecido como herói entre os seus e digno de respeito e honra até entre os inimigos. 
individuais e coletivos de conduta desde os hábitos saudáveis, a educação dos filhos, a religião, a ética e a filosofia. $\mathrm{O}$ crescimento exponencial do livre-arbítrio gerou o inverso da liberdade: o soterramento do indivíduo por um volume de informaçóes e opçóes além de sua capacidade de escolha. Como adverte o mesmo autor:

Presa entre fundamentalistas, que acreditam ter descoberto a verdade, e relativistas, que se recusam a fixá-la, a maioria desnorteada entre eles continua a esperar que haja uma verdade que valha a pena ser procurada, sem saber como proceder ou responder às vozes de cada extremo. (2000, p. 17)

Se o pleno é, ou por enquanto ainda é (na visão dos mais otimistas), inacessível, se está diante de um falso problema. A armadilha da qual se deve esquivar é a de abandonar o absoluto pelo absolutamente relativo, como se verá adiante, pois ao almejar o possível, não se pretende (nem serve) qualquer resposta, mas a melhor resposta alcançável. Assim, não se abdica da verdade, muito menos da luta por ela, mas aprende-se a conviver com a verdade realizável uma vez ser intangível a total. É importante manter o compromisso e todo o esforço para atingir a vontade possível. A herança cultural do ocidente repudia profundamente a conduta contrária. Aquele que se intitulou a verdade e o caminho foi posto em julgamento e, processado e sentenciado, foi crucificado. A história dos povos cristãos, todavia, condenou para sempre Pôncio Pilatos por "lavar as mãos". Difícil imaginar exemplo de maior força simbólica de morte da verdade pela omissão do julgador...

Por isso, o direito precisa operar na sociedade realizando, no sentido exato de tornar reais, suas prescriçóes hipotéticas regulatórias. O cumprimento de sua missão disto depende. Isto significa, em última análise, que deve operar sobre a verdade (fato reais) e de verdade (incidências corretas e efetivas). O processo representa a última chance de prevalência do direito, pois sua regra é a de ocorrer na ausência do adimplemento espontâneo. Assim, se veredicto pretende ser a "verdade dita", assim como a jurisdição tem a intenção de ser "a dicção do direito", a validade do sistema jurídico está em sua capacidade de operar com a verdade.

\section{A Linguagem: Signo e Verdade}

Ao se associar a verdade à comunicação, faz-se uma necessária referência à linguagem. O objeto que está presente não precisa ser significado, apenas indicado para efeito de ser comunicado. Quando a linguagem e a comunicação evoluíram e pretenderam referirse a algo ausente da percepçáo do destinatário surgiu o problema da correspondência, ou, de outra forma, da verdade, pois toda utilização da linguagem, tem o escopo de representar algo. Desde então se tornou palpável a importância da linguagem para a verdade. Para alcançá-la, por muito tempo, se optou pelo caminho da imparcialidade, da isençáo 
e da técnica na aplicação da linguagem, até que a impossibilidade de tais pretensôes foi desnudada pelo chamado "giro hermenêutico". Com efeito, após o "giro hermenêutico" patrocinado por Heidegger a partir do Século XIX, mostrou-se que a compreensão possui caráter existencial. $\mathrm{O}$ próprio Heidegger relacionou a compreensão com uma expectativa da própria existência humana.

Gadamer, por sua vez, acrescenta à hermenêutica filosófica a concepção que a interpretação ocorre na dimensão real existencial do intérprete, e, em relação ao direito, realça a importância do contexto histórico na interpretação jurídica como traduz Marcio Augusto de Vasconcelos Diniz "O jurista deve levar em conta o aspecto histórico ao interpretar a lei, para determinar o seu conteúdo normativo (sein normative Gehalt) e aplicá-la ao caso a que se dedica." (1998, p. 225) para acrescentar a concepção de interpretação como concretização do conteúdo da norma (1998, p. 225).

A realidade do processo de interpretação e as interferências do intérprete no objeto, porém, ao contrário do que possa parecer, não comprometem nem reduzem a importância do resultado. A pretensáo de um direito puro, imune as vicissitudes humanas, náo passou sequer pela cabeça de Kelsen. Nenhuma obra cultural pode pretender ser absoluta se relativo é o próprio homem e, sendo assim, o melhor direito que se pode produzir é aquele capaz de refletir a sociedade que o concebeu. $\mathrm{O}$ direito deve sim almejar a unidade, a coerência e a verdade, mas somente os alcançará dentro dos limites destas mesmas características na sociedade da qual emerge. Não se pretende aprofundar a discussão em torno das possibilidades e impossibilidades da linguagem, nem das interferências que seu uso, ou as trazidas pelo próprio intérprete produzem no resultado, pois sendo conhecida esta realidade da condição humana, nela não se pode ver mal. Errado apenas é ignorar tal circunstância, ou tentar simular que ela não existe.

A linguagem, assim, é uma ferramenta cuja obra dependerá da intenção do agente. Conhecer bem e compreender a linguagem é útil e desejado, mas supervalorizar sua importância para que apenas dela dependa o êxito, o insucesso ou até a impossibilidade da comunicação não se revela adequado nem produtivo. A linguagem, portanto, deve continuar a serviço da transmissão dos conceitos e ideias e da verdade, devendo sim os agentes da comunicação ter a dimensão de seu alcance para melhor atingir o escopo da troca intersubjetiva de conhecimentos teóricos ou práticos.

\section{A Verdade e o Direito}

O direito, ao disciplinar a conduta por normas hipotéticas e interferir na ação para conformá-la ao modelo posto, tem a reconhecida intenção de realizar-se a si mesmo, cumprindo, assim, seu papel na sociedade de equalizar a relação do homem com o tempo, estabilizando e, se possível e melhor, consolidando as expectativas dos indivíduos. O 
direito quer se realizar, quer virar história. Esta colocaçáo vem a propósito da perspicaz análise de Felipe Fernández-Armesto sobre um quadro de Goya que retrata a verdade, o tempo e a história:

Com um leve sorriso, quase imperceptível na mancha indistinta que Goya lhe deu por face, ela volta seu olhar do Tempo e da Verdade para nós, enquanto escreve seus registros em um livro. O Tempo está arrastando a Verdade até a presença da História, mas a História não parece preocupar-se. Enigmática, complacente, está mais interessada em sua plateia. (FERNÁNDEZ-ARMESTO, 2000, p. 16)

Admitir que o tempo pretende transformar o direito em história, tal como a verdade do quadro de Goya na interpretação de Felipe Fernández-Armesto, neste contexto, significa também compreender que a história está mais interessada na platéia do que na verdade ou no direito. A platéia, registre-se, não é a humanidade como gênero, pois a história é escrita apenas pelos vencedores e o direito, em regra, construído a serviço da proteção de seus interesses. A história, desta maneira, volta-se a platéia que quer agradar.

Olhando-se a situação no espelho, verifica-se que direito é constituído, assim, por verdades históricas que os vencedores construíram e consolidaram. Isto não o desqualifica ou desmerece, apenas o revela. A verdade buscada pelo direito, portanto, nunca foi (embora pretendesse ou fingisse pretender) uma verdade absoluta, mas apenas a verdade do arranjo de forças existente (e possível) numa determinada sociedade e num período específico. O direito, como advertia o saudoso Calmon de Passos em suas preleçóes, não administrava a Justiça, mas a maior quantidade tolerável de injustiça, até porque a norma jurídica tem, por essência, a finalidade de distinguir, desigualar, regular o acesso aos bens da vida que, interessando a muitos, não estejam disponíveis em quantidade suficiente para satisfazer a todos. O comprometimento do jurídico com os interesses que o inspiraram não lhe afasta da verdade, póe na mesa apenas a questão da legitimidade, que tem outra matriz, mas em nada corrompe seu conteúdo positivo no plano social, nem sua correlação com a verdade. É como adverte Fernández-Armesto:

Toda tentativa de ser melhor - toda tentativa de construir relaçóes felizes e sociedades prósperas - começa com duas questóes: como posso distinguir o certo do errado? E como posso distinguir o verdadeiro do falso? [....] Não há ordem social sem confiança, e não há confiança sem verdade, ou, no mínimo, sem procedimentos aceitos de apuração da verdade (FERNÁNDEZ-ARMESTO, 2000, p. 17)

A verdade almejada pelo direito é social e cultural e para atingir esta verdade são concebidos seus institutos, órgãos e procedimentos. Se há uma discussão nos ramos da ciência de qual caminho escolher para combater o relativismo entre as opçóes possíveis correspondência, coerência ou consenso - no caso das ciências culturais, a resposta há de 
ser por meio do consenso, especialmente do direito ${ }^{12}$. A passagem do Estado legislativo para o Estado constitucional também trouxe em suas mudanças esta no significado da interpretação jurídica e na compreensão do próprio direito, que passou a ser reconstruído a partir de núcleos de significado, dada a separação entre texto e norma, em função da qual se deslocou para o destinatários dos textos legislativos a outorga de seus sentidos normativos (MITIDIERO, 2014, 53). Este movimento desloca o centro de gravidade da ciência do direito, antes concentrado na legislação, em direção da jurisdição, da qual se aproxima. Em contrapartida, o processo civil, no Estado constitucional, passa a ter como fim a tutela dos direitos como forma de dar efetividade aos princípios da segurança jurídica e da dignidade da pessoa humana (MITIDIERO, 2104, 55), condicionada, entre outros requisitos "à adequada verificação da verdade das alegaçóes de fato formuladas pelas partes" na qual "ganha importância a colocação da verdade como objetivo da prova" (MITIDIERO, 2014, 65), de forma que "a decisão será tanto mais justa quanto maior for a abertura do processo para a busca da verdade" (MITIDIERO, 2014, 66), ainda que "o mais correto, mesmo, seria entender a verdade buscada no processo como aquela mais próxima possivel da real, própria da condição humana” (DIDIER JR, BRAGA, OLIVEIRA, 2015b, 47).

O direito, com efeito, não deve ser visto como um ente estático, muito menos diante das provas e da verdade. Não é uma obra acabada, nem mesmo pretende ser, seja porque se organizou para funcionar como uma profecia auto-realizável, uma hipótese sempre desafiando sua própria implementação, seja porque se vinculou a um equilíbrio de forças instável, cujas modificaçóes lhe afetam. O direito, este eterno vir a ser, portanto, resulta de sua própria construção consensual pela sociedade e - com mais intensidade - pelos operadores do direito, em primeiro lugar e acadêmicos, em segundo.

Por outro lado, o direito não obstante se estruture como ciência, evolui como arte, alterando seus paradigmas por meio de experiências emocionais. De fato, quando se reproduzem em série as fórmulas consagradas do direto posto e concretizado, vivencia-se a ação de um obra cultural dotada de aparente coerência e unidade, porém, todas as vezes que o direito precisa de um novo salto náo pode se amparar nos conceitos consolidados e depende da capacidade intuitiva de um operador capaz de criar um novo argumento sedutor o suficiente para ingressar no mundo jurídico dando a impressão que dele foi extraído, e nisto se assemelha a arte, a "grande arte" na interessante proposta de Felipe Fernandez-Armesto:

Quando a arte é "grande arte", quando nos dá uma convicção de verdade, o resultado raramente é qualificado como uma percepção intelectual,

12 Ainda é difícil obter a compreensão dos demais ramos do conhecimento da particularidade da relação íntima do direito com seu objeto, para o qual o distanciamento é impossível, pois se conhece estuda e faz direito ao mesmo tempo. Nas trincheiras da vanguarda do desenvolvimento "tecnológico" do direito quase sempre estão os operadores práticos, a maioria dos verdadeiros "cientistas" que constrói o direito e o conhecimento do direito do futuro. 
mas, antes, como uma experiência emocional, que modifica nossa relação com o mundo, em vez de acrescentar alguma coisa ao nosso conhecimento sobre ele. Talvez a mais rara e, portanto, mais rica experiência que possamos obter da contemplaçáo da arte seja uma suspeita de mundo possíveis que ainda não imaginamos, e, muito menos, experimentamos. (FERNÁNDEZ-ARMESTO, 2000, p. 203).

Náo teria sido isto que, por exemplo, fez o Promotor Heron Santana quando, para incluir sob o manto do ordenamento aqueles que a interpretação tradicional e estabelecida recusava, se valeu da aceitação do discurso científico para embasar na semelhança cromossômica a titularidade do direito à liberdade de uma primata usado como fulcro de um habeas corpus?

É importante ressalvar no episódio citado o porquê da propositura específica da ação de habeas corpus, se toda a fundamentação teórica já havia sido debatida no meio acadêmico por ocasião da defesa de sua tese de mestrado. A busca da decisão judicial, norma individual aderente ao patrimônio jurídico do sujeito titular do direito subjetivo, resulta da referida situação particular do direito, de acordo com a qual, não obstante a doutrina também seja reconhecida como fonte do direito, é na concretude das normas individuais que o jurídico se torna real, palpável. Embora se forme no consenso, o direito não quer apenas o convencimento, quer a efetivação. Daí a busca pelo reconhecimento da jurisdição.

O próprio Kelsen, em sua obra mais conhecida, apresenta-se o Poder Judiciário como criador de norma jurídica constitutiva, aquela individual que dará termo ao conflito ${ }^{\text {ii }}$, embora o reconhecimento do caráter normativo da decisão judicial conviva na obra, entretanto, com uma concepção na qual o preenchimento da moldura deduzida do ordenamento é feita pelo juiz com o que se designa por discricionariedade em direito público ${ }^{\mathrm{iii}}$.

Assim, a verdade para o direito é, ao mesmo tempo, sua matéria prima, enquanto fato do mundo fenomenológico, compromisso, enquanto escopo de sua existência quanto à concretizaçáo de suas prescriçóes e, no outro lado da moeda, o que de realmente ocorre por força de sua aplicação na sociedade. A verdade ingressa no sistema jurídico como fonte (fática) e retorna à sociedade, devolvida pelo ordenamento, como resposta jurídica efetiva (seja ela qual for, confirmadora ou informadora da norma geral hipotética pretensamente incidente). Não é por outro fator que a pragmática sociedade tem maior interesse - e atenção - nos pronunciamentos objetivos dos Tribunais do que na própria lei, ou, ainda muito menos, na doutrina. Como na música dos Titãs ${ }^{13}$, a sociedade só quer saber do que "pode dar certo". A verdade que deve alimentar o direito é a dos fatos (efetivamente

13 "Go back". De autoria de Torquato Neto e Sérgio Brito. 
ocorridos) e da construção (legítima) das normas concretas. A verdade que a sociedade se alimenta do direito é a norma individual, aquela que, "dá certo", acontece. Daí a importância do processo como meio de produção da última oportunidade do direito prevalecer: a decisão judicial. Não é casual a convergência do civil law com o common law.

\section{A Verdade e o Processo}

O processo - devido processo legal, cuja origem remonta à Magna Carta cujos 800 anos celebram-se neste ano - é uma das mais significativas conquistas do que se convencionou chamar de Estado Democrático de Direito. A adaptação da doutrina de Montesquieu ao Estado Democrático de Direito é fruto da evolução do constitucionalismo contemporâneo e contraria o pensamento original do ideólogo francês. $\mathrm{O}$ conceito de poder judiciário é o melhor exemplo disto, pois para Montesquieu, o Poder Judiciário era um poder invisível e "nulo"iv, destinado apenas a pronunciar as palavras da lei, esta norma elaborada pelo poder legislativo, plena e acabada, dotada de todos os elementos necessários à gerar os efeitos pretendidos teria nos julgadores apenas os tradutores técnicos do seu enunciado, daí a ausência de necessidade de legitimação democrática para sua atuação.

A ideia do Poder Judiciário autônomo, independente, e criador do direito individual, evoluiu juntamente com a sociedade e próprio conceito de Estado, inclusive para atender, ao mesmo tempo, a uma maior complexidade social que revelou inviável a criaçâo de um ordenamento jurídico pleno, capaz de elucidar todas as possíveis controvérsias, e à transformaçáo radical experimentada na evolução histórica do conceito de lei que abandonou sua acepçấo original de norma geral e abstrata destinada a orientar e regular a conduta humana com neutralidade, para tornar-se um "fato político", um instrumento de governo utilizado pelo poder político para realização de seu próprio projetov".

Mas, a evolução das instituiçôes sociais e políticas transformou todas as funçôes do Estado, afastando-as das concepçôes originais de Montesquieu, e, no caso do Poder Judiciário, dando especial relevo à suas atribuições e tornando-o poderoso, como adverte Pinto Ferreira ${ }^{\text {vi }}$, inclusive na qualidade de guardiáo da Constituição. Com efeito, cada mudança ocorrida no mundo, tornando-o mais complexo e dinâmico, trazia consigo uma defasagem na legislação, aumentando a distância entre a capacidade dos órgãos legislativos normatizarem todas as possíveis novas condutas, ao tempo que ampliava a esfera de interesses dos jurisdicionados e, conseqüentemente, o potencial de conflito.

Para contornar esta situação, as atribuiçôes do Poder Judiciário na solução dos litígios tiveram que ser gradativamente ampliadas para viabilizar sua utilização instrumental. Por outro lado, a lei deixou de ser um ente racional pretensamente equidistante com inspiração ética e filosófica, para amoldar-se a uma racionalidade "político-tecnológica" 
tornando-se ele próprio também parte de um "processo de governo"14. Em função disto, o Poder Judiciário teve paulatinamente modificada sua atuação inicial de árbitro desinteressado para solucionar conflitos entre terceiros, para órgáo de administraçáo da justiça e, portanto, diante da mudança no conceito de lei, instrumento de garantia da legalidade, ou seja, de eficácia da política vii , o guardiāo do pacto social atualizado, porque "assegura, por suas decisóes, a soberania da justiça, isto é, a realização dos direitos individuais nas relaçôes sociais" ${ }^{\text {viii }}$, ou promove a harmonia social ${ }^{\text {ix }}$ por meio de uma atuaçáo independente ${ }^{x}$, o que, de forma alguma, imunizaria o jurídico da crise de legitimidade que assola a maioria das instituições humanas como prega Antônio de Pádua Ribeiro ${ }^{\text {xi }}$.

Neste quadro ressurge a questão da verdade, pois se uma idéia simplista admitia que o processo somente buscava a verdade por meio da persecuçáo dos fatos sobre os quais deveria ser projetado o modelo da norma hipotética, a realidade revela que o processo judicial contemporâneo transformou-se em um mecanismo de construçáo do direito efetivo que, destinado originalmente a confirmar o ordenamento substantivo, é, muitas vezes, tanto quem lhe decreta a morte, quanto quem lhe ressuscita (atualizado, aperfeiçoando, etc.).

A criação judicial do direito designa uma corrente do pensamento jurídico que tem inclinado-se cada vez mais para valorizar a norma individual contida na sentença, transformando gradativamente o processo de dizer (declarar) o direito em construir o direito no caso concreto. A idéia da criação judicial do direito - objeto da dissertaçáo de mestrado de José Guilherme de Souza - não é nova, estando presente no pensamento das escolas da jurisprudência teleológica (jurisprudência de interesses - Rudolf Von Ihering, escola da livre pesquisa científica - François Gény) e do direito livre (freie Rechstschule - Ehrliche) baseada na idéia nuclear de Stammler de que "todo direito deve ser uma tentativa de direito justo". Na mesma linha, Kantorowicz, inclusive, propóe, negando a concepçáo estatal do direito, a existência de normas jurídicas oriundas do grupo social, expressão da livre vontade dos homens que deveriam servir de inspiração à decisão do juiz. Alinharam-se ainda nas fileiras da produçáo do direito pela atividade jurisdicional, inobstante com concepçóes próprias, Oliver Wendell Holmes, Roscoe Pound, Benjamim Cardoso, Jonh Chipman Gray, Karl Llewellyn, Jerome Frank, Alf Ross, Olivecrona, Lundstedt, Axel Hägerstrom. Exemplo recorrente da admissão desta nova postura seria o de Piero Calamandrei em sua obra clássica ao referir-se ao Juiz que, convencido por sua consciência da decisão mais justa, busca depois os fundamentos para sustentar lógica e juridicamente sua decisão $o^{\text {xii }}$.

Até o positivismo, ao menos na obra clássica de Kelsen, já admitia a funçáo normativa da decisão judicial ${ }^{\text {xiii }}$, não apenas como parte do processo originado pelo legislador, mas

14 A ingenuidade iluminista de tentar reduzir o político ao jurídico fora suplantada pela instrumentalização política do jurídico. 
também em caráter originário seja para preencher lacunas ${ }^{\mathrm{xiv}}$, seja para corrigir iniquidades da norma ${ }^{\mathrm{xv}}$. O problema do positivismo é que aceita a discricionariedade, como já visto, abrindo mão da coerência científica que propóe, uma vez que a norma de competência não se revela suficiente para legitimar a criação da norma individual. A questão da inserção da atividade jurisdicional no ordenamento e de sua legitimidade também não encontra solução satisfatória em propostas voluntaristas ou vinculadas à uma idéia de razão subjetiva do juiz.

Assim, se a captação da verdade dos fatos é favorecida pelo desenvolvimento tecnológico da sociedade, ao menos no plano das ocorrências que interessam ao direito, a construção da verdade da incidência e a efetividade da resposta tornam-se diariamente desafios mais complexos. A busca da verdade é, neste contexto, apontada como "um dos princípios essenciais do processo - senão a função principal do processo" (MARINONI, ARENHART, MITIDIERO, 2015b, 244).

É preciso, por isso, construir um conceito de prestação jurisdicional capaz de atender aos desafios da modernidade, ou seja, simultaneamente contribuir para a segurança jurídica ${ }^{\text {xvi }}$ pela distribuição da justiça e agir legitimamente nos moldes requeridos pelo Estado Democrático de Direito $^{\text {xvii }}$. Para isso, necessariamente, precisar transpor as fronteiras estabelecidas pela visão primária de Montesquieu e transbordar a moldura do positivismo.

Se a jurisdição é uma atividade capaz de - e cada dia mais destinada a - produzir direito, torna-se necessário traçar os parâmetros desta construção ${ }^{\text {xviii }}$ a ser balizada pelas três formas de legitimação que o desenvolvimento das sociedades concebeu para a jurisdição: o procedimento, a fundamentação e o diálogo.

É evidente, em primeiro lugar, que o Poder Judiciário desenvolveu um método de atuação - procedimento - cujas regras após sua consolidação passaram a representar para o jurisdicionado uma garantia. O princípio do devido processo legal prescreve que o Poder Judiciário deve respeitar a lei enquanto atua, e que a norma individual somente terá validade para o caso concreto se derivar de um procedimento regular desenvolvido de acordo com regras preestabelecidas, aplicando uma lei material preexistente. Não é demais recordar que as origens históricas do princípio do devido processo legal referemse ao direito da terra da Magna Carta, ou seja, às normas aplicáveis como as vigentes no território do jurisdicionado, razão pela qual a questão de validade da norma material é também uma questão de due process of law, como nos ensina Hugo Lafayette Black ${ }^{\mathrm{xix}}$.

A legitimação pelo procedimento decorre também na relação cada dia mais estreita entre os princípios processuais e as normas constitucionais fundamentais ${ }^{\mathrm{xx}}$. Por esta razão, especialmente considerando-se a necessidade do Poder Judiciário exercer uma jurisdição que o credencie não apenas perante os interessados no processo, mas perante a sociedade também, é importante que seus pronunciamentos revistam-se da necessária e suficiente 
fundamentação, buscada, notadamente, na Constituição ${ }^{x x i}$ para se legitimar como verdadeira $^{\text {xxii }}$ tornando-se socialmente eficaz por ser capaz de construir e reconstruir a sociedade a partir dela mesma ${ }^{\mathrm{xxiii}}$.

Por fim, a busca da verdade no direito e, em especial, no processo, não há de se satisfazer apenas com ritos (procedimento) e argumentos (fundamentação), mas precisará incluir a legitimação pelo diálogo, requisito do consenso que é o caminho para a recuperação do compromisso com a verdade. $\mathrm{O}$ caminho opcional do STF em casos polêmicos - como o da pesquisa com células tronco - foi institucionalizado pelo NCPC $\left(927, \$ 2^{\circ}\right.$; 983; 1038, II)

Neste sentido, o pensamento de Jürgen Habermas sobre a legitimação pela ação comunicativa, não obstante desenvolvido pelo autor para a atividade de produção legislativa, oferece elementos de grande utilidade e de boa aplicação na criação da norma individual por meio da jurisdição.

Assim, embora o próprio Habermas, autor desta concepção, tenha feito de forma clara sua opção por não aplicar a ação comunicativa na construção do direito pela jurisdição, tenta-se exatamente desenvolver a aplicação prática deste procedimento de legitimação pelo diálogo consistente, engajado e qualitativo para que, junto com a legitimaçáo formal pelo procedimento e pela fundamentaçáo, seja possível construir também uma legitimação material para a atividade jurisdicional, que, se não for capaz de atender a todos as expectativas que a sociedade deposita no direito e no Poder Judiciário, pelo menos se revela mais adequada para arriscar suas chances neste hercúleo trabalho, cuja execução parece somente ser possível para o mais capaz dos homens: o homem coletivo - homem comunicativo.

O processo é constituído de ritos, dialética e tempo. Da mistura destes ingredientes extrai-se o direito. O processo, desta maneira, revela-se o campo adequado para a construção do direito que desafia a sociedade nestes novos tempos. Um direito capaz de extrair da realidade e da sociedade verdade e, igualmente, devolver-lhe verdade e, com isso, segurança (jurídica e social) e convivência harmônica.

\section{A Verdade e a Repartição Dinâmica da Prova no NCPC}

Em processo, verdade - no plano fático, se associa à prova, já que controvérsia fática é a tônica das demandas judiciais. A correlação verdade, prova, processo e direito transformou o direito à prova em um direito fundamental (MARINONI, 2015a, 504). Registrese que verdade, direito e processo não são conceitos unívocos, não sendo diferente com prova "una famiglia di concetti e cui membri mostrano varie carattieristiche analoghe ma anche rilevanti differenze" (TARUFFO, 2014a,75), motivo de serem referidos por gênero. 
O direito à prova (em sua amplitude) contempla, entre outros aspectos, a correlação teleológica entre prova e verdade e a distribuição adequada do ônus da prova (MARINONI, 2015a, 505). Esse direito fundamental (DIDIER JR, BRAGA, OLIVEIRA, 2015b, 41) também está previsto em tratados internacionais incorporados ao direito brasileiro, como a Convenção Americana de Direitos Humanos (Pacto de São José da Costa Rica), incorporado pelo Decreto no 678-9, no seu art. $8^{\circ}$ e o Pacto Internacional dos Direitos Civis e Políticos, incorporado pelo Decreto n o 592/92, no seu art. 14.1, alínea "e". O $\$$ $3^{\circ}$ do art. $5^{\circ}$ da Constituição Federal prevê que os tratados e convençôes internacionais sobre direitos humanos que forem aprovados, em cada Casa do Congresso Nacional, em dois turnos, por três quintos dos votos dos respectivos membros equivalerão às emendas constitucionais.

O Novo Código de Processo Civil do Brasil deixa transparecer sua preocupação com a efetivação do direito por meio do processo ao, entre outras posturas: vincular o processo civil à Constituição Federal (art. 1 oxxiv); estabelecer o princípio da cooperação (art. $6^{\text {oxxv }}$; submeter a atividade jurisdicional a princípios norteadores (art. $8^{\text {oxxi }}$ ); exigir e objetivar a

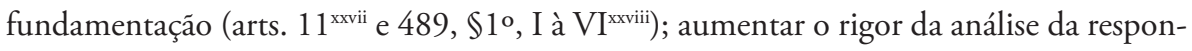
sabilidade das partes por sua conduta em Juízo, até mesmo por pleitear indevidamente a gratuidade da justiça (art. 100, par. ún.), e; parametrizar pela boa-fé objetiva a conduta de todos os partícipes do processo (art. 50) e a interpretação do pedido (art. 322, \$2º e da decisão judicial (art. 489, \$3º)

No mesmo sentido e de forma mais específica, reforçou o papel da busca da verdade na formação da decisão judicial em diversas passagens, revelando, assim a consciência do legislador desta correlação e de sua importância na realização da missão do Poder Judiciário. Com efeito, além de manter o dever de expor os fatos conforme a verdade, a Lei $13.105 / 15$ incluiu expressamente os procuradores entre os destinatários da norma (art. 77 , ${ }^{x x i x}$ ) repetindo a alteração da verdade (art. 80, II) como hipótese de má-fé processual sujeita a reparação de perdas e danos, honorários e multa (ampliada em até dez vezes - art. 81) em favor da parte contrária (art. 96). Até mesmo os efeitos da revelia, reconhecidamente duros no direito brasileiro, foram amainados no texto em favor da formação de uma verdade processual mais próxima da real, seja por meio de sua inaplicabilidade quando os fatos forem inverossímeis ou conflitantes com a prova dos autos (art. 345, IV ${ }^{\mathrm{xxx}}$ ), seja pelo reconhecimento do direito do revel à produçáo de provas (art. 349 ${ }^{\mathrm{xxxi}}$ ). O NCPC também passou a prever expressamente (art. 139, VI) a proatividade do juiz na condução do processo comprometida com "maior efetividade à tutela do direito" inclusive quanto à ordem de produção da prova.

É possível conjecturar, com alguma razão, acerca da desnecessidade da expressão literal de muitos destes dispositivos que poderiam ser deduzidos da ordem constitucional ou mesmo dos princípios informadores do direito, inclusive do ramo específico do processo, 
mas o senso de necessidade que moveu o legislador para tais inclusóes retrata o reconhecimento da distinção prática entre, por exemplo, consagrar na Constituição o princípio da fundamentação (CF 93, IX) e obter decisôes dos órgãos jurisdicionais efetivamente legitimadas democraticamente por sua motivação.

Não obstante a importância de apontar a preocupação do texto do Novo Código de Processo com a relação entre verdade, processo e direito, até para contribuir na concepção do plexo de valores que anima sua intepretação, o objetivo desta abordagem é concentrar o foco no papel da introdução - renovadora - da proposta da carga probatória dinâmica neste contexto do Processo Civil ${ }^{15}$.

O Código de Defesa do Consumidor (Lei 8.078/90) já previa, entre os direitos básicos do consumidor, a possibilidade de inversão do ônus da prova em favor do consumidor quando, a critério do juiz, fosse "verossimil a alegaçâo" e/ou fosse ele "hipossuficiente, segundo as regras ordinárias de experiência” (CDC, art. 60. VIII ${ }^{\mathrm{xxxii}}$ ), tendo esta regra inspiração no princípio da isonomia (NERY JR, NERY, 2015, 996). A disposição sobre ônus probante fora da regra geral do interesse, assim, não é inovadora, mas é renovadora ao trabalhar por outro prisma e com mais cautela. De fato, a lógica protecionista do micro sistema jurídico criado pelo CDC sustenta a regra benéfica à tutela dos interesses sociais que gravitam em torno das relaçóes de consumo e de seus protagonistas, ainda que não ampare - pela violaçáo dos princípios constitucionais da ampla defesa e do contraditório - a interpretação extensiva por meio da qual se passou a defender e aplicar a possibilidade de tal inversão ser procedida na prolação da sentença inspiradora de proposta de reforma do CDC em discussão com a inclusão de tal possibilidade no texto legal.

O Novo Código de Processo Civil, cuja amplitude busca alcançar enorme diversidade de natureza tanto cível, quanto de outros $\operatorname{ramos}^{16}$ (art. 15), requer uma abordagem distinta da regulação de uma distribuição do ônus probatório feita pelos $\$ \$$ do art. 373 por critério diverso do interesse do litigante. Com efeito, prevê o $\$ 1^{\circ}$ do art. $373^{\text {xxiii }}$ a possibilidade do juiz, mediante decisão fundamentada e sempre assegurando a parte a oportunidade de desincumbir-se do ônus, excepcionar a clássica regra do ônus da prova fundada no interesse nos casos: a) previstos em lei; b) de impossibilidade ou excessiva dificuldade de cumprir o encargo pela regra geral; c) maior facilidade de obtenção da prova do dato contrário. Tal deliberação não pode gerar situação na qual " a desincumbência do encargo pela parte seja impossivel ou excessivamente difícil” (art. 373, \$2 ${ }^{\circ}$ ). O NCPC ainda

15 No processo penal, substancial do direito penal, já que não há culpado sem decisão passada em julgado, em que o dever de provar é da acusação, pois a incerteza beneficia o réu, o papel da prova é outro e maior, pois destes enunciados deduz-se que não haverá incidência do direito penal sem a prova do crime, de sua autoria e da culpabilidade do réu.

16 A aplicação subsidiaria e supletiva nos processos eleitorais, trabalhistas e administrativos dos $\$ \$$ do art. 373 é um dos temas tangentes mais instigantes trazidos pela Lei 13.105/15. 
prevê a possibilidade da distribuição do ônus da prova ser ajustada por convenção das partes (art. 373, $\$ 3^{\circ}$ ), antes ou durante o processo (art. 373, $\$ 4^{\circ}$ ) exceto quando recaia sobre direito indisponível da parte e/ou torne excessivamente difícil o exercício do direito a uma das partes. Esta dissociação da prova das partes e de seus interesses individuais se confirma no artigo $371^{\text {xxxiv }}$.

Este conjunto de parágrafos inaugura uma abordagem diferenciada sobre a relação entre verdade, prova, processo e direito e permite e requer reflexóes sobre sua contribuição para o papel do processo na construção e efetivação do direito material. Antes de refletir sobre a inovação, deve-se buscar sua compreensão.

A teoria da carga probatória dinâmica em sua gênese no direito portenho (OLIVEIRA, 2014, 21), no qual sua utilização nos 21 anos de sua criação tem sido excepcionalíssima, se inspira no princípio da cooperação ao propor a determinação pelo juiz do ônus de provar para "aquele que estiver, no processo, em melhor condição de fazê-lo" (NERY JR, NERY, 2015, 997).

Os dispositivos do NCPC, todavia, não elegem exatamente a facilidade para produzir a prova como critério de distribuição do ônus e, como a interpretação é restritiva, por se tratar de regra de exceçáo, sua aplicabilidade deve ser circunscrita às hipóteses legais. Com efeito, além dos “casos previstos em lei", o $\$ 1^{\circ}$ do art. 373 prevê como hipóteses da redistribuição a impossibilidade ou excessiva dificuldade para aquele a quem incumbiria a prova pelo regime geral e/ou a maior facilidade de obtenção da prova contrária, sempre limitada pela impossibilidade ou dificuldade excessiva do destinatário da redistribuição. Em resumo, os casos são de dificuldade de quem deveria trazer a prova ou facilidade da prova em sentido contrário. Exemplos auxiliam a compreensão: é muito difícil para um cliente de um banco provar que a instituição procedeu alteraçóes na cronologia dos lançamentos feitos em sua conta corrente ${ }^{\mathrm{xxxv}}$, tarefa simples para o banco, se compelido a trazer aos autos os registros ou permitir a perícia de seus sistemas. Esta prova também poderia ser trazida pelo Banco Central, caso retivesse as informaçóes necessárias. Nas açóes relativas a erros médicos, causa da criação da teoria na Argentina (OLIVEIRA, 2014, 21), também tem cabido a atribuição do ônus da prova aos hospitais e médicos (Revista dos Tribunais, 811 , p. 43). Em um caso de dano moral fundado requerido por vítima de envolvimento amoroso com pessoa que omitiu estado civil de casado ou existência de união estável anterior, a prova de que alguém é solteiro, ou livre e desempedido é quase impossível, enquanto a prova do fato contrário é possível e relativamente fácil.

Segundo a regra do NCPC, a distribuição do ônus da prova deverá ser decidida pelo juiz no saneamento (art. 357, III), mas as hipóteses que autorizam a aplicação excepcional do instituto, por sua própria natureza, muitas vezes ocorrem - ou se revelam - no curso da instruçáo, motivo pelo qual se deve concluir que o juiz pode deliberar 
fundamentadamente pela aplicação do $₫ 1^{\circ}$ do 373 no curso da instrução, ou após seu término, desde que propicie ao destinatário a oportunidade de desincumbir-se do ônus como exige o texto legal (DIDIER JR, BRAGA, OLIVEIRA, 2015b, 125), reabrindo a instrução se for o caso, ao contrário do que propóem Nelson Nery e Rosa Maria Nery $(2015,998)$ que não admitem tal decisão após conclusos os autos.

Apesar de parte da doutrina não conferir importância (MARINONI, ARENHART, MITIDIERO, 2015b, 267), é preciso notar a existência de uma distinção entre inversão do ônus e distribuição dinâmica do mesmo (OLIVEIRA, 2014, 22), que, afinal, não constituem exatamente a mesma coisa. A inversão, como prevista no CDC, é a aplicaçáo ao contrário da regra do ônus, determinando-se à parte contrária o prejuízo processual que seria da parte beneficiada. A distribuição, ainda que possa, em muitas circunstâncias, ensejar como consequência a aplicaçáo reversa da regra do ônus, confere mais liberdade ao juiz para dividir entre os litigantes, no intento de melhor instruir o feito, a parcela de cada um na produção da prova. A inversão, pura e simples, transfere o ônus de um lado para o outro, e sobrecarrega a parte que não teria interesse/atribuição de instruir o feito, da consequência na solução da controvérsia fática do insucesso da instrução. A distribuição permite ao magistrado buscar a instrução do feito com a colaboração de todos os envolvidos, decidindo como melhor instruir o processo com a participação das partes, o que pode significar a partição da responsabilidade entre autores, réus e terceiros no processo.

Apresentado o novel instituto, a primeira reflexão se dirige à natureza da regra que dispóe sobre a produção da prova, pois, náo obstante a preservação da nomenclatura consagrada, há uma modificação no instituto a solicitar um exame. Com efeito, a produção da prova sempre foi atribuída aos litigantes como ônus por força da perfeita adequaçáo do instituto à hipótese, já que ao estabelecer o destinatário da regra definidora da parte sobre a qual recaía tal atribuição, verificava-se a lógica do interesse equivalente à incidência do ônus - aquele tipo de prescrição de conduta cuja inobservância acarreta prejuízo ao sujeito destinatário da norma de conduta.

Assim, se a inobservância de um dever jurídico acarreta uma sanção específica e a de uma obrigação sua exigibilidade pelo sujeito titular da pretensão, o ônus distingue-se assim da obrigação e do dever pela consequência de sua inobservância ser a imputação de um prejuízo, sem, contudo, se poder exigir adimplemento positivo nem aplicar sançáo específica. Com efeito, o descumprimento do dever de boa-fé processual acarreta a aplicação de multa ao litigante, a recusa à obrigação de outorgar escritura pública de transferência de imóvel quitado autoriza o Poder Judiciário a substituir a vontade do sujeito passivo e determinar ao Cartório de Imóveis proceder ao regular registro, mas, ao litigante que não se desincumbe do ônus de prova, se pode apenas prejudica-lo na apreciação de seu pleito. A distinção fundamental é que se pode estabelecer sanção específica pela parte não se desincumbir do ônus nem obrigar uma parte a fazer a prova. 
Esta lógica, todavia, é quebrada pela distribuição do ônus da prova por critério que não seja o interesse próprio, pois, a rigor, se está criando a obrigação de trazer a prova para juízo, até como corolário dos princípios da cooperação, expressamente incorporado pelo artigo $6^{\circ}$ do NCPC e da verdade real, cuja adoção na Lei 13.105/15 se extrai da análise de dispositivos dispersos (como os arts. 345, IV, 349, 371, 380, par. ún., 400, par. ún., 403, par. ún., 435, par. ún., 479), mesmo que, inexplicável e injustificadamente, o NCPC tenha previsto no direito processual civil a concepção de que a parte tem o amplo direito de não produzir prova contra si (art. 379 ${ }^{\text {xxxi }}$ ), de constitucionalidade duvidosa (MARINONI, ARENHART, MITIDIERO, 2015b, 256), ainda que o artigo que a desobriga especificamente seja mais restritivo (art. 388 ${ }^{\mathrm{xxxvii}}$ ). Há um equilíbrio natural na associação do ônus ao interesse em função da qual se estabelece uma relação proporcional entre a consequência jurídica do desatendimento à regra do ônus - se o interessado foi inerte, prejudica-se em relação ao seu próprio interesse. Ao se distribuir o ônus da prova por critério distinto do interesse no esclarecimento do fato, permitindo-se que o mesmo seja atribuído à parte que não tem interesse na demonstração daquele fato, ao revés, ou, em outras palavras, quando se obriga uma das partes a trazer aos autos prova em favor da outra contra a qual está litigando, a natureza da relação jurídica se modifica, pois se transforma a produção de prova em juízo, neste caso, em dever da parte, como já reconhecem doutrinadores (MARINONI, ARENHART, MITIDIERO, 2015b, 253), corroborados pelo texto do art. 378 do $\mathrm{NCPC}^{17}$, cuja sanção processual passa a ser a própria atribuição do ônus, que, ao final, pode acarretar o êxito da parte adversária na demanda. O dever de cooperação atinge todos (378) inclusive terceiros que podem ser sancionados por náo colaborar (400, par. ún.).

Há substancial diferença entre perder uma ação por não ter feito a prova necessária para demonstrar a existência de seu direito de sucumbir na demanda por não ter produzido nos autos a prova contrária àquela necessária e útil ao oponente. Isto porque, ao se compelir o litigante a colaborar com a Justiça contra si se precisa admitir que a conjugação dos princípios da verdade real e da cooperação tornaram a produção de provas um dever, não mais um ônus, a despeito do disposto no art. 379 do NCPC. A distinção é tanta que Nelson Nery Jr e Rosa Maria Andrade Nery $(2015,997)$ chegam a enxergar (sem razão ${ }^{18}$ ) inconstitucionalidade por violação ao princípio de direitos humanos vigente no Brasil

17 O texto repete o art. 339 do $\mathrm{CPC} / 73$, mas a distribuição dinâmica da prova confere-lhe outro alcance.

18 Não obstante a opiniấo de Nelson Nery e Rosa Maria Nery, a distribuição dinâmica somente faz sentido quando determinar ônus distinto daquele previsto na lei, norteado pelo interesse. Taxar de inconstitucional toda distribuição que exigir prova contrária ao interesse esvazia o instituto em favor de um princípio que tem toda relevância no direito processual penal, mas que no processo civil inviabilizaria a aplicação do princípio da cooperação em matéria probatória, atingindo os princípios da verdade real e da instrumentalidade do processo, quando a garantia fundamental do processo penal não tem a mesma função ou alcance no processo civil. 
de que ninguém pode ser obrigado a produzir prova contra si mesmo $\left(\mathrm{CIDH}\right.$, art. $8^{\circ}, 2$ $\left.\mathrm{g}^{\mathrm{xxxviii}}\right)$, cujo teor, a rigor, veda apenas que o réu em acusaçóes de delitos seja obrigado a depor contra si mesmo ou declarar-se culpado.

A distinção do início do parágrafo anterior não tem conotação de crítica, pois ambos os princípios - verdade real e cooperação - alinham-se perfeitamente com a instrumentalidade do processo ${ }^{19}$, norte essencial da consagração do devido processo legal como meio de concretização do direito e não de sua postergação ou negação. $\mathrm{O}$ objetivo é o de fazer a reflexão para melhor compreender a nova dimensão do instituto, pois apenas a partir da noção de prova como dever se pode entender a amplitude da proposta do Novo Código de Ritos na nova dimensão dada Às partes para atuação no processo.

Duas consideraçóes prévias se impóem ainda. Realçar a necessidade da decisão fundamentada nos termos do artigo 11 do NCPC, que, embora o dispositivo se refira aos requisitos da sentença, remete aos incisos do $\$ 1^{\circ}$ do art. 489 do NCPC, pois a tônica do código cidadão é a da legitimação da jurisdição pelo procedimento, pela fundamentação e até, em certos casos, pelo diálogo com terceiros interessados (art. 138) e com a sociedade (arts. 927, $\$ 2^{\circ}, 983,1.038$, II). Registrar a necessidade de assegurar à parte para a qual se distribuir o ônus probante fora da regra geral a oportunidade de desincumbir-se do mesmo, refutando, assim, a redistribuição na sentença (DIDIER JR, BRAGA, OLIVEIRA, 2015b, 125) $)^{20}$, corolário óbvio do princípio da ampla defesa infelizmente mal compreendido por parte da doutrina (NERY JR, NERY, 2015, 997) e da jurisprudência (apesar do STJ já ter repelido este entendimento ${ }^{\text {xxxix }}$ ) construída sobre a interpretação do Código de Defesa do Consumidor ${ }^{21}$. Atendidos aos requisitos, a redistribuição poderia ser determinada pelo juiz nas hipóteses do NCPC.

A primeira hipótese - os casos previstos em lei, como o CDC ou outros que poderão ser construídos (de lege ferenda), normalmente adequado para microssistemas jurídicos de natureza protetiva -, por buscar sua legitimação democrática no próprio processo legislativo não representa maior desafio para análise instrumental do processo. Não que a mera previsão em lei da distribuição distinta seja suficiente para comprometer o processo com a busca e a produção da verdade, mas, que, em função de sustentar-se em uma decisão

19 Mesmo deslocado o eixo do processo instrumento do juiz para processo instrumento da sociedade, toda ampliaçáo do papel e da atuação das partes no processo náo o desvinculou de sua finalidade como caminho para efetivação do direito, ao contrário.

20 Sem razão, portanto, Nelson Nery e Rosa Maria Nery ao cogitar da redistribuição do ônus na sentença $(2015,997)$, seja por ofensa literal aos próprios $\$ \$ 1^{\circ}$ e $2^{\circ}$ do art. 373 do NCPC, seja, aí sim, por violação aos princípios do devido processo legal, da ampla defesa e da instrumentalidade.

21 É conhecido o entendimento - flagrantemente inconstitucional - de que o inciso VIII do art. $6^{\circ}$ do CDC permite a inversão do ônus da prova na sentença - encerrada a instruçáo, não obstante a violaçáo ao princípio da ampla defesa. A ideia inspira proposta de texto de reforma do CDC em tramitação legislativa no qual tal aberração teria consagração literal no texto. Espera-se que o texto do NCPC freie este ímpeto. 
legislativa prévia, não se permitir a verificação de pertinência da medida como quando se trata de decisão casuística. Em outras palavras, se norma legislativa de caráter genérico previu a redistribuição do dever de provar, não há suficiente margem na decisão judicial para sua análise sob a ótica da contribuição positiva ou negativa na construção da verdade necessária ao julgamento.

Com efeito, é na crítica das decisóes judiciais nos casos de impossibilidade ou excessiva dificuldade de cumprir o encargo pela regra geral ou maior facilidade de obtenção da prova do dato contrário que se torna necessária a apuração dos efeitos reais da inovação legislativa na aproximação da verdade do processo. O próprio NCPC já estabelece alguns parâmetros, como a vedação à que a redistribuição gere situação na qual " a desincumbência do encargo pela parte seja impossivel ou excessivamente difícil” (art. 373, \$2 $2^{\circ}$ ) è disposição por ato das partes quando recaia sobre direito indisponível e/ou torne excessivamente difícil o exercício do direito a uma das partes (art. 373, $\$ 3^{\circ}$ ).

Estes limites, todavia, não são suficientes para assegurar que a redistribuição não produza um efeito maléfico sobre o processo, afastando-o de sua finalidade maior: a confirmação da validade e eficácia do ordenamento, pois é preciso conscientizar os operadores do direito, notadamente o magistrado, que a decisão sobre a redistribuição do dever de provar precisa estar vinculada exatamente a este propósito de trazer ao processo a informação necessária à boa decisão de mérito.

A aplicação do direito ao fato concreto - atividade predominante do Poder Judiciário que somente analisa direito em tese na via excepcional do controle concentrado de constitucionalidade - presume o conhecimento do fato concreto. A prova, quase sempre, tem por objeto a controvérsia fática, tendo por objeto teor e vigência do direito (municipal, estadual, consuetudinário ou estrangeiro) apenas excepcionalmente (art. 376), motivo pelo qual é evidente que a condução da instrução objetiva precipuamente o aclaramento do suporte fático de forma a permitir ao órgão jurisdicional aplicar o ordenamento sobre uma situação sobre a qual não paire dúvida. Neste sentido é importante lembrar ser a finalidade primária da instrução a eliminação de todas as divergências relevantes existente no processo sobre o caso posto a exame judicial, uma condiçấo de se poder falar em uma decisão comprometida e vinculada a uma "verdade" objetiva. Somente se o magistrado está convencido de ter adquirido o conhecimento em derredor dos fatos se pode falar em uma aplicação segura de sua decisão jurídica (ainda que esta possa ser questionada em suas ilações e conclusóes).

Se o fato não restou esclarecido os autos, a decisão, ainda que formalmente válida, perde o compromisso com a realização concreta do direito e isso é tanto possível quanto - infelizmente - frequente em função da vedação ao non liquid (art. 140) obrigar o juiz a decidir mesmo sem ter certeza do direito e a própria regra do ônus da prova a deliberar sem convicção sobre os fatos. 
O ideal, obviamente, é que o juiz forme sua convicção sobre a divergência fática da análise da prova (art. 371), pois isto lhe oferta a base sobre a qual aplicar o direito. Todavia, mesmo não convencido, deve decidir, restando-lhe, pela ordem, aplicar uma presunção jurídica e, na sua falta, a regra do ônus da prova, caso no qual decidirá a controvérsia fática em desfavor de quem não se desincumbiu do ônus. Evidente que em ambos os casos - presunção legal ou aplicação da regra do ônus - a verdade formal que servirá para decisão judicial é fictícia e desgarra a aplicação do direito da certeza quanto aos fatos que deveria lhe preceder. $\mathrm{O}$ fracasso da instrução em dirimir as dúvidas fáticas, assim, assinala que o processo perdeu o compromisso com a verdade, relativizando-o. Toda decisão interlocutória ou sentença fundada em presunção legal ou ônus probatório contém per si um risco potencial de aplicação do direito sobre uma não verdade.

Este parêntese sobre os níveis de convicção do magistrado acerca do suporte fático é necessário para ressaltar que a distribuição do ônus probatório somente atende as finalidades precípuas do processo quando contribui para a produção da verdade alcançável no processo, formando a convicção do juiz e permitindo ao mesmo aplicar o direito com segurança acerca das circunstâncias em derredor da causa. Fora disso, servirá apenas para fornecer outro critério de construção de uma verdade formal igualmente fictícia descomprometida com a verdade real e insuficiente para a prestaçáo jurisdicional almejada pelo NCPC.

Importante realçar, até porque é um tema esquecido pelos doutrinadores, que a "facilidade de produzir a prova" normalmente se apresenta em face de um meio específico de prova, podendo ocorrer tanto que o mesmo fato possa ser comprovado por outro meio disponível para ambos os litigantes, ou que a disponibilidade daquele meio específico não seja razão suficiente para transferir o ônus para a parte. Haverá por certo circunstâncias nas quais o juiz determinará a prova para uma parte, sem contudo, atribuir-lhe o ônus, tendo que contentar-se com outras sançóes processuais pela inobservância do dever.

Com isso se pretende afirmar que, não obstante a utilidade dos limites traçados pelo próprio NCPC, a decisão do magistrado sobre a redistribuição do ônus - especialmente em relação à sua fundamentação - deve perseguir esta finalidade maior: propiciar os meios à colação aos autos das informaçóes e documentos necessários à formação dos elementos de certeza necessários a deliberação, promovendo o diálogo qualificado cogitado por Habermas.

As hipóteses legais, mesmo que úteis para definir situaçôes nas quais não se deve modificar a partição do ônus da prova, não são suficientes para determinar quando se deve decidir pela redistribuição, pois este exame, a ser feito caso a caso, pede a compreensão pelo Juízo de como propiciar efetivamente a formação de seu conhecimento, sendo este o fundamento que deve ser exigido da decisão para justificar a modificação do sistema 
tradicional, sob pena de transformar-se o novel dispositivo num instrumento de afastamento do processo da verdade e, portanto, distanciamento da jurisdição da justiça.

\section{Conclusão: 0 Processo, o Direito e a Verdade no NCPC}

O processo pode ser descrito como a busca pelo direito, na realidade social, das verdades necessárias à análise dos fatos e das incidências, para devolver, à própria sociedade, a verdade do direito, essencial para que a sociedade se visualize no espelho e, desta maneira, possa (re)conhecer o direito e regular sua conduta em conformidade com ele. A ausência da verdade tem sido sentida na sociedade, em especial, da falta da verdade do direito.

De fato, uma das funçóes do Poder Judiciário é a resolver os conflitos jurídicos na sociedade, mas outra é fornecer a ultima ratio do direito, aquela que retorna em forma de verdade para a sociedade. A criação judicial do direito, convive com uma jurisdicização da vida, do que se origina um aumento da demanda por justiça e uma ampliação das expectativas de obter no Poder Judiciário a plenitude da vivência dos direitos assegurados pelo ordenamento. A sociedade testa a verdade do direito, que somente poderá ser obtida, no campo da prestação jurisdicional por sua tripla legitimação: pelo procedimento; pela fundamentação e pelo diálogo comunicativo entre os agentes comunicativos nos moldes imaginados por Habermas, no que constitui campo fértil o processo ${ }^{22}$.

Em relação ao procedimento, na condução do processo, o que o magistrado procura assegurar através da fiel observância de vários princípios, entre os quais o do devido processo legal, da ampla defesa, do contraditório, do juiz natural, da vedação da produção de provas por meios ilícitos, da publicidade, da ubiqüidade como caminho para uma decisão justa, porque tais institutos não constituem um fim em si mesmo, mas traduzem o resultado da evolução da experiência na produção do direito processual, e existem especialmente com o escopo de criar a condição para que o provimento jurisdicional reflita efetivamente a realidade (verdade) fática e jurídica do caso.

Quanto à fundamentação, é por meio dela que o Magistrado se comunica não apenas com as partes, mas (talvez até mais importante) com a sociedade, especialmente para atingir os efeitos (sociais, não jurídicos), sua insuficiência esvazia o sentido da jurisdição, sua presença alcança diretamente o objetivo maior da produção individual do direito: pacificar a sociedade (mais do que ao conflito específico).

A inclusão do diálogo comunicativo seria a novidade, não resultasse muito mais de uma constatação ${ }^{23}$ do que de uma proposição. Não que isto retire a importância do efetivo

22 Ao contrário do que propôs o próprio Habermas que sugeria ser na atividade legislativa que a ação comunicativa deveria ocorrer.

23 De que, apesar da objeção de Habermas, é no processo que a ação comunicativa que propôs de fato ocorre com mais perfeita simetria com os elementos cogitados por sua teoria. 
estabelecimento de um diálogo, o mais aberto quanto possível com a sociedade, especialmente quando o tema o exigir ${ }^{24}$, mas o propósito maior é mesmo realçar a importância deste elemento na legitimação da jurisdição.

A verdade do direito, porém, não pode ser atingida apenas com a construção procedimental, fundamentada e dialógica da aplicação do ordenamento sem buscar-se a delimitação precisa da situação fática sob exame, condição não apenas para a mera incidência da norma ou estabelecimento do diálogo em derredor da tutela, mas também da própria implantação do arrojado projeto do NCPC (a uniformização de jurisprudência, a formação e a aplicação de precedentes requer definição precisa do suporte fático, tanto na construção da razão de decidir, quanto na operação da distinção e da superação dos precedentes).

Neste sentido se examinou uma das inovaçóes da Lei 13.105/15 - a distribuição dinâmica da carga probatória - com escopo de, pela análise das hipóteses de cabimento e não cabimento da redistribuição diversa da carga probatória, buscar os parâmetros para concluir pelo condicionamento do acerto da decisão de impor a uma das partes o dever de efetivar prova contra seus próprios interesses no atendimento dos princípios da verdade real e da cooperação, ou seja, de sustentar que a excepcionalidade da invocação pelo magistrado deste novo instituto esteja condicionada à finalidade de formar convicçáo, evitando o caminho fácil e perigoso da facilitação de obtenção de uma verdade formal e fictícia, descompromissada com a verdade real, e, por consequência, com a confirmação do ordenamento, finalidade primeira e última do direito processual.

\section{Referências}

ASSIER-ANDRIEU, Louis. O direito nas sociedades humanas. Trad. por: Maria Ermantina Galvão.Trad. de: Le droit dans les sociétés humaines. São Paulo: Martins Fontes, 2000.

BARBOSA, Rafael Vinheiro Monteiro, MAIA, Maurilio Casas. Isonomia dinâmica e vulnerabilidade no direito processual civil. Revista de Processo. Ano 39, vol. 230, abril/2014, pp. 349/365. São Paulo: Revista dos Tribunais, 2014.

BLACK, Hugo Lafayette. Crença na Constituição. Tradução por Luiz Carlos F. de Paula Xavier. Tradução de: A contitutional faith. Rio de Janeiro: Forense, 1970.

CALAMANDREI, Piero. Direito processual civil. Trad. por: Luiz Abezia e Sandra Drina Fernandez Barbiery. Campinas: Bookseller, 1999, Vol.1.

CÂMARA, Alexandre Freitas. Liçóes de direito processual civil. 25 a Ed. São Paulo: Atlas, 2014.

24 Como fez o STF, ao analisar a questấo das células tronco e propóe o NCPC (arts. 927, \$2º, 983, 1038, II). 
CARNIO, Henrique Garbellini. Filosofia do direito processual e procedimentalização do direito. Revista de Processo. Ano 39, vol. 231, maio/2014, pp. 367/378. São Paulo: Revista dos Tribunais, 2014.

CHIARILONI, Sergio. Uma perspectiva comparada da crise na justiça civil e dos seus possíveis remédios. Revista de Processo. Ano 38, vol. 228, fevereiro/2014, pp. 325/329. São Paulo: Revista dos Tribunais, 2014.

COSTA, Guilherme Recena. Livre convencimento e standards de prova. In: $\mathbf{4 0}$ anos da teoria geral do processo no Brasil: passado, presente e futuro. Camilo Zufelato e Flávio Luiz Yarshell (Org.). São Paulo: Malheiro, 2013.

COSTA, Maria Isabel Pereira da. Constitucionalismo ou neoliberalismo: o que interessa a quem?. Porto Alegre: Síntese, 1999.

DIDIER JR, Fredie, BRAGA, Paula Sarno, OLIVEIRA, Rafael Alexandria. Curso de direito processual civil: introduçáo ao direito processual civil, parte geral e processo de conhecimento. 17a . Ed. Salvador: Jus Podivm, 2015a, v.1

Curso de direito processual civil: teoria da prova, direito probatório, decisão, precedente, coisa julgada e tutela provisória. 10a . Ed. Salvador: Jus Podivm, 2015b, v.2

DINIZ, Marcio Augusto de Vasconcelos. Constituição e hermenêutica constitucional. Belo Horizonte: Mandamentos, 1998.

FARIA, José Eduardo. Globalizaçáo econômica e reforma constitucional. In: Revista dos Tribunais. São Paulo: Revista dos Tribunais, ano 86, v. 736, p. 11-19, 1997.

FARIA, Márcio Carvalho. A lealdade processual, o projeto de novo Código de Processo Civil brasileiro e a experiência portuguesa. Revista de Processo. Ano 39, vol. 230, abril/2014, pp. 369/396. São Paulo: Revista dos Tribunais, 2014.

FERNÁNDEZ-ARMESTO, Felipe. Verdade: uma história. Trad. por: Beatriz Vieira, Trad. de: Truth: a history. Rio de Janeiro: Record, 2000.

FERREIRA FILHO, Manoel Gonçalves. Direitos humanos fundamentais. 2. ed. São Paulo: Saraiva, 1998.

FERREIRA, Pinto. Curso de Direito Constitucional. 7a Ed. São Paulo: Saraiva, 1995.

FRIEDE, Reis. Curso Analítico de Direito Constitucional e de Teoria Geral do Estado. Rio de Janeiro: Forense, 1999.

GRECO, Leonardo. A teoria geral do processo e a prova. In: 40 anos da teoria geral do processo no Brasil: passado, presente e futuro. Camilo Zufelato e Flávio Luiz Yarshell (Org.). São Paulo: Malheiro, 2013.

GUERRA FILHO, Willis Santiago. Autopoiese do Direito na Sociedade Pós-moderna. Porto Alegre: Livraria do Advogado, 1997. 
HABERMAS, Jürgen. Direito e democracia: entre facticidade e validade. Trad. de Faktizität und Geltung. Beiträge zur Diskurstheorie des Rechits und des demokratische Rechitstaats. 4a ed.Trad. por Flávio Beno Siebeneichler. Rio de Janeiro: Tempo Brasileiro, 1997, Vols. I e II.

HART, Herbert L. A. . O conceito de direito. Trad. por: A. Ribeiro Mendes. Trad. de: The concept of law. 2. ed. Lisboa: Edição da Fundação Calouste Gulbenkian, 1996.

HÖFFE, Otfried. Justiça política: fundamentação de uma filosofia crítica do direito e do Estado. Trad. por: Ernildo Stein. Trad. de: Politische Gerechtigkeit. Grundlegung einer kritischen philosophie von recht und staat. 3a. ed. São Paulo: Martins Fontes, 2006.

IHERING, Rudolf Von. A luta pelo direito. Rio de Janeiro: Rio, 1975.

KELSEN, Hans. Teoria Pura do Direito. São Paulo: Martins Fontes, 1998.

LASKI, Harold J.. El problema de la soberania. Tradução por Armando Bazán. Tradução de: Studies in the problem os sovereignty. Buenos Aires: Ediciones Siglo Viente, [s.d.].

LEAL, André Cordeiro. O contraditório e a fundamentação das decisóes no direito processual democrático. Belo Horizonte: Mandamentos, 2002.

LESSA, Pedro. Do poder judiciário. Rio de Janeiro: Francisco Alves, 1915.

LIMA, Fernando Antônio Negreiro. Teoria geral do processo judicial. São Paulo: Atlas, 2013.

LIRA, Ricardo César Pereira. Formação e seleção dos juízes no Brasil: A missáo do Juiz em um país do terceiro mundo. In: VI Jornada Teixeira de Freitas: unidade do sistema jurídico e identidade latino-americana, p. 65-72, [s.l.: s.e.], 1997.

LOMBARDI, Eduardo. La Organización del Poder Judicial en Uruguay. In Revista da Faculdade de Direito das Faculdades Metropolitanas Unidas, Série Internacional, ano 10, v. 16, jul-dez.1996, São Paulo: Apamagis, 1996.

MARCATO, Antonio Carlos. Algumas consideraçóes sobre a crise da justiça. In: $\mathbf{4 0}$ anos da teoria geral do processo no Brasil: passado, presente e futuro. Camilo Zufelato e Flávio Luiz Yarshell (Org.). São Paulo: Malheiro, 2013.

MARINONI, Luiz Guilherme ARENHART, Sérgio Cruz. Prova. São Paulo: Revista dos Tribunais, 2009.

MARINONI, Luiz Guilherme, ARENHART, Sérgio Cruz, MITIDIERO, Daniel. Novo curso de processo civil: teoria do processo civil, volume I. São Paulo: Revista dos Tribunais, 2015. 
. Novo curso de processo civil: teoria do processo civil, volume 1. São Paulo: Revista dos Tribunais, 2015a.

Novo curso de processo civil: tutela dos direitos mediante procedimento comum, volume 2. São Paulo: Revista dos Tribunais, 2015 b.

MITIDIERO, Daniel. A tutela dos direitos como fim do processo civil no Estado Constitucional. Revista de Processo. Ano 39, vol. 229, março/2014, pp. 51/74. São Paulo: Revista dos Tribunais, 2014.

MONTESQUIEU, Charles Louis de Secondat, Barão de Bredè e. O espírito das leis. Tradução por Cristina Murachco. São Paulo: Martins Fontes, 1996.

NASCIMENTO, Walter Vieira do. A justiça. Rio de Janeiro: Forense, 2000.

NERY JR, Nelson, NERY, Rosa Maria de Andrade. Comentários ao código de processo civil: novo CPC - lei 13.105/2015. São Paulo: Revista dos Tribunais, 2015.

OLIVEIRA, Vivian von Hertwig Fernandes de. A distribuição do ônus da prova no processo civil brasileiro: a teoria da distribuição dinâmica. Revista de Processo. Ano 39, vol. 231, maio/2014, pp. 13/36. São Paulo: Revista dos Tribunais, 2014.

PAULA, Jônatas Luiz Moreira de. Teoria geral do processo. Leme: Led, 1999.

RIBEIRO, Antonio de Pádua. O judiciário como poder político no século XIX. In: Revista Sintese de Direto Processual Civil. Porto Alegre: Síntese, v. 1, n. 1, set./out., 1999.

ROCHA, Cármem Lúcia Antunes. O direito constitucional à jurisdiçáo. In: TEIXEIRA, Sálvio de Figueiredo (Coord.). As Garantias do cidadão na Justiça. São Paulo: Saraiva, p. 31-51, 1993.

ROCHA, Fernando Luiz Ximenes. Direitos fundamentais na Constituição de 1988. In: Os 10 anos da Constituição Federal: temas diversos. Coord. Alexandre de Moraes. São Paulo: Atlas, 1999.

RODRIGUES, Marcelo Abelha. Elementos de Direito Processual Civil. 2. ed.. São Paulo: Revista dos Tribunais, 2000, v. 1.

RULLI JÚNIOR, Antonio, SANTOS, Antonio Carlos Viana. MERCOSUL: espaços de integração, soberania, jurisdiçáo, harmonizaçáo, cidadania, Tribunal de justiça supranacional do Mercosul, Parlamento do Mercosul. São Paulo: Juarez de Oliveira, 2001.

SANDEL, Michael J.. Justiça: o que é fazer a coisa certa. $12^{a}$. ed. Trad. de: Justice. Trad. por: Heloísa Matias e Maria Alice Máximo. Rio de Janeiro: Civilização Brasileira, $2013 a$. 
O que o dinheiro náo pode comprar: os limites morais do mercado. Trad. de: What Money can't buy. Trad. por: Clóvis Marques. Rio de Janeiro: Civilização Brasileira, 2012.

. Contra a perfeição: ética na era da engenharia genética. Trad. de: The case against perfection. Trad. por: Ana Carolina Mesquita. Rio de Janeiro: Civilização Brasileira, 2013b.

SILVA, Clarissa Sampaio. A efetividade do processo como um direito fundamental: o papel das tutelas cautelar e antecipatória. In: Dos direitos humanos fundamentais. Org. Willis Santiago Guerra Filho, p. 183-203. Porto Alegre: Livraria do Advogado, 1997.

SILVA, José Afonso. Aplicabilidade das normas constitucionais. 3. ed. São Paulo: Malheiros, 1998.

SILVA, Ovídio A. Baptista da. Curso de Processo Civil. 4. ed. São Paulo: Revista dos Tribunais, 1998, v. 1.

SOUSA, Miguel Teixeira de. Algumas questôes sobre o ónus de alegação e de impugnação no novo processo civil português. Revista de Processo. Ano 38, vol. 228, fevereiro/2014, pp. 311/324. São Paulo: Revista dos Tribunais, 2014.

SOUZA, José Guilherme de. A criação judicial do direito. Porto Alegre: Sérgio Antonio Fabris, 1991.

SPENGLER, Fabiana Marion, SPENGLER NETTO, Theobaldo. A boa-fé e a cooperação previstas no PL 8.046/2010 (novo CPC) como princípios viabilizadores de um tratamento adequado dos conflitos judiciais. Revista de Processo. Ano 39, vol. 230, abril/2014, pp. 13/32. São Paulo: Revista dos Tribunais, 2014.

TARUFFO, Michele. Il concetto di "prova” nel diritto processuale. Revista de Processo. Ano 39, vol. 229, março/2014, pp. 75/87. São Paulo: Revista dos Tribunais, 2014 a.

. Veritá e processo. Revista de Processo. Ano 38, vol. 228, fevereiro/2014, pp. 63/78. São Paulo: Revista dos Tribunais, 2014 b.

WAMBIER, Luiz Rodrigues, TALAMINI, Eduardo. Curso avançado de processo civil: teoria geral do processos e processo de conhecimento, volume 1. 15 $\mathrm{a}$ Ed. Sáo Paulo: Revista dos Tribunais, 2015.

WAMBIER, Teresa Arruda Alvim, et. al. Primeiros comentários ao novo código de processo civil: artigo por artigo. Coord. Teresa Arruda Alvim Wambier. São Paulo: Revista dos Tribunais, 2015a.

WAMBIER, Teresa Arruda Alvim, et. al. Breves comentários ao novo código de processo civil: artigo por artigo. Coord. Teresa Arruda Alvim Wambier, et al.. São Paulo: Revista dos Tribunais, 2015b. 
YARSHELL, Flávio Luiz. Investigação e autonomia do direito à prova: um avanço necessário para a teoria geral do processo. In: $\mathbf{4 0}$ anos da teoria geral do processo no Brasil: passado, presente e futuro. Camilo Zufelato e Flávio Luiz Yarshell (Org.). São Paulo: Malheiro, 2013.

\section{Notas}

i Mas é sobretudo a evolução jurídica que requer ser esclarecida desse modo: a rigor, o desenvolvimento de uma religiáo, de uma arte, de um corpo de ciências tal como a geometria, de uma indústria tal como a dos metais ou dos tecidos, pode ser explicada separadamente; o desenvolvimento de um corpo de Direito náo; pois o Direito, entre outras ciências sociais, tem o caráter distintivo de ser, como a língua, não só parte integrante mas também espelho integral da vida social. (TARDE, Gabriel. Les transformations du droit. Paris: Berg, 1994, p. 188, apud ASSIER-ANDRIEU, Louis. O direito nas sociedades humanas. Trad. por: Maria Ermantina Galvão.Trad. de: Le droit dans les sociétés humaines. São Paulo: Martins Fontes, 2000, p 310).

Uma decisão judicial não tem, como por vezes se supóe, um simples caráter declaratório, $\mathrm{O}$ juiz não tem simplesmente de descobrir e declarar um direito já de antemão firme e acabado, cuja "descoberta” do Direito ou juris- "dição" ("declaração" do Direito) neste sentido declaratório. A descoberta do Direito consiste apenas na determinação da norma geral a aplicar ao caso concreto. E mesmo esta determinação não tem um caráter simplesmente declarativo, mas um caráter constitutivo. (......) Só através da verificação, efetuada na decisão judicial, de que uma norma geral a aplicar ao caso apresentado perante o tribunal é vigente - e tal norma é vigente quando foi criada constitucionalmente -, se torna esta norma aplicável ao caso concreto e se cria, através dela, para este caso, uma situação jurídica que antes da decisão não existia. (......) Somente a falta de compreensão da função normativa da decisão judicial, o preconceito de que o Direito apenas consta de normas gerais, a ignorância da norma jurídica individual, obscureceu o fato de que a decisão judicial é tão-só a continuação do processo de criação jurídica e conduziu ao erro de ver nela apenas a função declarativa. (KELSEN, Hans. Teoria Pura do Direito. São Paulo: Martins Fontes, 1998, pp. 264-265).

iii "A norma jurídica geral é sempre uma simples moldura dentro da qual há de ser produzida a norma jurídica individual. Mas esta moldura pode ser mais larga ou mais estreita. Ela é o mais larga possível quando a norma jurídica geral positiva apenas contém a atribuição de poder ou competência para a produção da norma jurídica individual, sem preestabelecer seu conteúdo.” (KELSEN, Hans. Teoria Pura do Direito. São Paulo: Martins Fontes, 1998, p. 272) 
iv MONTESQUIEU, Charles Louis de Secondat, Barão de Bredè e. O espírito das leis. Tradução por Cristina Murachco. São Paulo: Martins Fontes, 1996, p. 172 SILVA, Ovídio A. Baptista da. Curso de Processo Civil. 4. ed. São Paulo: Revista dos Tribunais, 1998 , v. 1, p. 26

vi Nos derradeiros anos aumentou a influência do Poder Judiciário. Se, a princípio, era um órgão de pouca influência, e praticamente subordinado aos demais órgãos, hoje não somente é um órgão distinto, mas poderoso. (FERREIRA, Pinto. Curso de Direito Constitucional. $7^{\text {a }}$ ed. São Paulo: Saraiva, 1995, p. 473.)

$\mathrm{Na}$ verdade, o crescimento avassalador do Estado moderno está intimamente ligado ao monopólio da produção e aplicação do direito, portanto, à criação do direito, seja em nível legislativo, seja no nível jurisdicional (SILVA, Ovídio A. Baptista da. Curso de Processo Civil. 4. ed. São Paulo: Revista dos Tribunais, 1998, v. 1, p. 23.)

viii MENDES, João. O processo criminal brasileiro apud FERREIRA, Pinto. Curso de Direito Constitucional. 7a ed. São Paulo: Saraiva, 1995, p. 472.

ix O Poder Judiciário concorre para a harmonia e o equilíbrio da sociedade. O seu objetivo é traduzir a realidade efetiva do direito, aplicando a justiça nas relaçóes humanas. (FERREIRA, Pinto. Curso de Direito Constitucional. $7^{\text {a }}$ ed. São Paulo: Saraiva, 1995, p. 472).

Dificilmente poderia supor-se um Estado de Direito sem a existência de um Poder Judiciário autônomo e independente. É uma fórmula consagrada pela doutrina contemporânea. A prática das Constituiçóes náo a repeliu: ao contrário, a consolidou. (FERREIRA, Pinto. Curso de Direito Constitucional. $7^{\text {a }}$ ed. São Paulo: Saraiva, 1995, p. 472).

xi 11. A Lei e a Justiça "compóem as duas faces deste universo sobre o qual gravitam todos os fenômenos jurídicos”. Há uma crise da Lei e uma crise da Justiça. Essas crises decorrem da "distorção entre a lei e os anseios sociais" e da "ineficiência da realização da justiça”. Daí que, com inteira pertinência, destacou o Des. LUIS FUX que "resplandece no céu do terceiro milênio, encartada numa das 'Eras do Direito', idealizadas pelo notável NORBERTO BOBBIO, a 'Era da Legitimidade', resultante das novas expectativas quanto à 'lei e à justiça', emergentes das respostas à crise jurídica que agoniza no mundo que ora contemplamos. (RIBEIRO, Antonio de Pádua. O judiciário como poder político no século XIX. In: Revista Síntese de Direto Processual Civil. Porto Alegre: Síntese, v. 1, n. 1, set./out., 1999, p. 19). por Ary dos Santos. Tradução de Elogio dei Giudici scritto da un avvocato. 5. ed. Lisboa: Livraria Clássica, 1975, pp. 145-146). 
xiii Somente a falta de compreensão da função normativa da decisão judicial, o preconceito de que o Direito apenas consta de normas gerais, a ignorância da norma jurídica individual, obscureceu o fato de que a decisão judicial é tão-só a continuação do processo de criação jurídica e conduziu ao erro de ver nela apenas a função declarativa. (KELSEN, Hans. Teoria pura do direito. Tradução por João Baptista Machado. Tradução de: Reine rechtslehre. 6. ed. São Paulo: Martins Fontes, 1998, p. 265)

xiv Por isso, o tribunal que tem que decidir o caso precisa colmatar esta lacuna pela criação de uma correspondente norma jurídica. (KELSEN, Hans. Teoria pura do direito. Tradução por João Baptista Machado. Tradução de: Reine rechtslehre. 6. ed. São Paulo: Martins Fontes, 1998, p. 273).

Porém a aplicação da ordem jurídica vigente pode ser considerada como não eqüitativa ou desacertada, não apenas quando esta não contenha uma norma geral que imponha ao demandado ou acusado uma determinada obrigação, mas também quando ela contenha uma tal norma. (KELSEN, Hans. Teoria pura do direito. Tradução por João Baptista Machado. Tradução de: Reine rechtslehre. 6. ed. São Paulo: Martins Fontes, 1998, p. 274).

xvi Fossem eles a opinião particular dos Juízes, e viver-se-ia na sociedade sem saber precisamente quais os compromissos assumidos. (MONTESQUIEU, Charles Louis de Secondat, Baron de Bredè e. O espírito das leis. Tradução por Pedro Vieira Mota. São Paulo: Saraiva, 1987, p. 168).

xvii Na verdade, o importante é não tanto proibir ao juiz de sentir, de valorar, de preferir, mas obter critérios hermenêuticos com fundamento nos quais as suas próprias escolhas não se distanciem das escolhas que o povo, soberanamente, no Estado Democrático contemporâneo, positivou na Constituição, princípio e fim último de toda atividade do intérprete. (DINIZ, Márcio Augusto de Vasconcelos. Constituição e hermenêutica constitucional. Belo Horizonte: Mandamentos, 1998, p. 272.)

xviii No avanço da técnica, mera extensão do homem, deve a ciência estar submetida à moral? $\mathrm{O}$ mito do desconhecido deve ser normatizado pela jurisdição? As novas descobertas trazem novos conflitos, além de incertezas para o futuro e a jurisdição é sempre a expectativa de segurança do homem e de sua sobrevivência no futuro. A jurisdição existe para garantir o futuro do homem, porque consciência e liberdade crescem conjuntamente”. (RULLI JÚNIOR, Antonio, SANTOS, Antonio Carlos Viana. MERCOSUL: espaços de integração, soberania, jurisdição, harmonização, cidadania, Tribunal de justiça supranacional do Mercosul, Parlamento do Mercosul. 1. ed. São Paulo: Juarez de Oliveira, 2001, p. 19.) 
xix É universalmente reconhecido que, no conceito de "lei da terra" da Magna Carta, está a origem da expressão constitucional "processo legal". Como indicou o Professor Dick Howard, da Escola de Direito da Universidade de Virgínia, no seu comentário sobre a Magna Carta, já em 1354, as palavras "processo legal" foram usadas num estatuto inglês de interpretaçáo da Magna Carta, e, no fim do século XIV, as expressōes "processo legal" e "lei da terra" eram permutáveis. Quando os colonizadores ingleses se fixaram em nosso país, trouxeram consigo a expressão "processo legal" e, mais tarde, usaram-na muito naturalmente, na Quinta Emenda do "Bill of Rights". Enraizada na história da Magna Carta, esta locução era, para eles, a garantia de que o governo não lhes tiraria a vida, a liberdade ou a propriedade, sem um julgamento feito de acordo com a lei da terra, existente ao tempo em que uma suposta ofensa fosse cometida. A Cláusula de "Processo Legal" da Quinta Emenda dá, assim, a todos os americanos, quem quer que sejam e onde quer que se encontrem, o direito de serem julgados por tribunais independentes e imparciais, de acordo com processos reconhecidos e não-discriminatórios e com leis válidas preexistentes. (BLACK, Hugo Lafayette. Crença na Constituição. Tradução por Luiz Carlos F. de Paula Xavier. Tradução de: A contitutional faith. Rio de Janeiro: Forense, 1970, p.53).

Em sendo assim, os princípios vetores do direito processual possuem sede constitucional, de forma que Processo e Constituição estão intimamente relacionados.

Conforme esclarece o Prof. Cândido Dinamarco: 'a Constituição age sobre o processo, garantindo-lhe princípios básicos, para que o processo possa, depois, atuar convenientemente os preceitos e garantias que ela própria contém e que projeta sobre todo o ordenamento jurídico'.

Da análise do art. $5^{\circ} \mathrm{da}$ CF vislumbram-se diversas garantias de ordem processual, tais como: a garantia do devido processo legal (inc. LIV), o princípio do juiz natural e a conseqüente proibição de juízo ou tribunal de exceção (inc. LIII e XXXVII), o princípio do contraditório e ampla defesa com todos os recursos e meios a ela inerentes (inc. LV), o princípio da inocência (inc. LVII), a publicidade dos atos processuais (inc. LX), a garantia da inafastabilidade da jurisdição (inc. XXXV).

Por outro lado, cumpre esclarecer que a existência da chamada tutela constitucional do processo tem como escopo assegurar a conformação dos institutos do direito processual com os princípios e fundamentos que descendem da própria ordem constitucional, bem como o reforço do sistema de garantias do cidadão. (SILVA, Clarissa Sampaio. A efetividade do processo como um direito fundamental: o papel das tutelas cautelar e antecipatória. In: Dos direitos humanos fundamentais. Org. Willis Santiago Guerra Filho, p. 183-203. Porto Alegre: Livraria do Advogado, 1997, p. 185-186) 
xxi Além disso, a Constituição Federal de 1988 abre caminho para uma aplicação mais justa do Direito, consagrando a teoria dos direitos fundamentais, partindo de princípios efetivos e não simplesmente programáticos, que são fundamentos da República mesma.

A Constituição estabelece que a República tem como fundamento a dignidade da pessoa humana, declara que é objeto fundamental dessa mesma República erradicar a pobreza e a marginalização, e reduzir as desigualdades sociais e regionais. De outro lado, explicita mais fortemente a função social da propriedade, condenando a propriedade não-utilizada e sub-utilizada.

Dessa forma, esses princípios, sobretudo para um magistrado do terceiro mundo, presidem efetivamente toda a aplicação e aplicação do direito infraconstitucional, de maneira a conduzi-lo à eqüidade e à Justiça Social.

Esses princípios fundamentais estão acima dos princípios gerais de que cuida a Lei de Introdução ao Código Civil, como instrumentos de integração e suprimento das lacunas do ordenamento.

Dita concepção dos direitos fundamentais centrados na Constituição já se faz sentir em vários momentos do fenômeno dinâmico da aplicação do direito, revelando a sensibilidade dos magistrados. (LIRA, Ricardo César Pereira. Formação e seleção dos juízes no Brasil: A missão do Juiz em um país do terceiro mundo. In: VI Jornada Teixeira de Freitas: unidade do sistema jurídico e identidade latino-americana, p. 65-72, [s.l.: s.e.], 1997, p.70).

xxii A “verdade" declarada na decisão é, portanto, uma verdade meramente persuasiva - primeira e primordial função do discurso ideológico do poder, em contrapartida ao discurso repressivo do poder -, porque pode prescindir, até, de correspondência com os fatos, de momento que subsunção destes à norma supre aquela correspondência e eleva, pelo discurso, ao nível de verdadeiro o que é apenas verossímil, isto é, aquilo que parece crível e é, em qualquer hipótese, ideologicamente preferível. (SOUZA, José Guilherme de. A criação judicial do direito. Porto Alegre: Sérgio Antonio Fabris, 1991, p.83)

xxiii Opinião de Luiz Fernando Coelho, apud José Guilherme de Souza “... uma sentença é significativa, não porque corresponda a algum fato ou represente uma conclusão analítica, mas simplesmente porque "funcionou" como portadora de significado [suporte de significações] dentro de uma formação social” (SOUZA, José Guilherme de. A criação judicial do direito. Porto Alegre: Sérgio Antonio Fabris, 1991, p. 46)

xxiv Art. $1^{\circ} \mathrm{O}$ processo civil será ordenado, disciplinado e interpretado conforme os valores e as normas fundamentais estabelecidos na Constituição da República Federativa do Brasil, observando-se as disposiçóes deste Código. 
XXV xxvi

xxvii Art. 11. Todos os julgamentos dos órgãos do Poder Judiciário serão públicos, e fundamentadas todas as decisóes, sob pena de nulidade.

xxviii 498 [...] $\$ 1^{\circ}$ Não se considera fundamentada qualquer decisão judicial, seja ela interlocutória, sentença ou acórdão, que:

I - se limitar à indicação, à reprodução ou à paráfrase de ato normativo, sem explicar sua relação com a causa ou a questão decidida;

II - empregar conceitos jurídicos indeterminados, sem explicar o motivo concreto de sua incidência no caso;

III - invocar motivos que se prestariam a justificar qualquer outra decisão;

IV - não enfrentar todos os argumentos deduzidos no processo capazes de, em tese, infirmar a conclusão adotada pelo julgador;

$\mathrm{V}$ - se limitar a invocar precedente ou enunciado de súmula, sem identificar seus fundamentos determinantes nem demonstrar que o caso sob julgamento se ajusta àqueles fundamentos;

VI - deixar de seguir enunciado de súmula, jurisprudência ou precedente invocado pela parte, sem demonstrar a existência de distinção no caso em julgamento ou a superação do entendimento.

xxix Art. 77. Além de outros previstos neste Código, são deveres das partes, de seus procuradores e de todos aqueles que de qualquer forma participem do processo:

I - expor os fatos em juízo conforme a verdade;

XXX

Art.345. [...] IV - as alegaçóes de fato formuladas pelo autor forem inverossímeis ou estiverem em contradição com prova constante dos autos.

xxxi Art. 349. Ao réu revel será lícita a produção de provas, contrapostas às alegaçóes do autor, desde que se faça representar nos autos a tempo de praticar os atos processuais indispensáveis a essa produção.

xxxii VIII - a facilitação da defesa de seus direitos, inclusive com a inversão do ônus da prova, a seu favor, no processo civil, quando, a critério do juiz, for verossímil a alegação ou quando for ele hipossuficiente, segundo as regras ordinárias de experiências. 
xxxiii $\$ 1^{\circ}$ Nos casos previstos em lei ou diante de peculiaridades da causa relacionadas à impossibilidade ou à excessiva dificuldade de cumprir o encargo nos termos do caput ou à maior facilidade de obtenção da prova do fato contrário, poderá o juiz atribuir o ônus da prova de modo diverso, desde que o faça por decisão fundamentada, caso em que deverá dar à parte a oportunidade de se desincumbir do ônus que lhe foi atribuído.

xxxiv Art. 371. O juiz apreciará a prova constante dos autos, independentemente do sujeito que a tiver promovido, e indicará na decisão as razóes da formação de seu convencimento.

xxxv Neste sentido: STJ, 2a Seção, REsp 1133872-PB, Rel. Min. Massami Uyeda, j. 14.12.2011, DJUE 28.3.11

xxxvi Art. 379. Preservado o direito de náo produzir prova contra si própria, incumbe à parte:

I - comparecer em juízo, respondendo ao que lhe for interrogado;

II - colaborar com o juízo na realização de inspeção judicial que for considerada necessária;

III - praticar o ato que lhe for determinado.

xxxvii Art. 388. A parte não é obrigada a depor sobre fatos:

I - criminosos ou torpes que lhe forem imputados;

II - a cujo respeito, por estado ou profissão, deva guardar sigilo;

III - acerca dos quais não possa responder sem desonra própria, de seu cônjuge, de seu companheiro ou de parente em grau sucessível;

IV - que coloquem em perigo a vida do depoente ou das pessoas referidas no inciso III.

Parágrafo único. Esta disposição não se aplica às açóes de estado e de família.

xxxviii Artigo 8. Garantias judiciais [....]. 2. Toda pessoa acusada de delito tem direito a que se presuma sua inocência enquanto não se comprove legalmente sua culpa. Durante o processo, toda pessoa tem direito, em plena igualdade, às seguintes garantias mínimas: [....] g. direito de não ser obrigado a depor contra si mesma, nem a declarar-se culpada;

xxxix STJ, 2a Turma, AgRgREsp 1450473-SC, Rel. Min. Mauro Campbell Marques, j. 23.9.14, DJUE 30.09.14 